Brit. F. vener. Dis. (1970) 46, 349

\title{
Treponema pertenue under the electron microscope*
}

\author{
N. M. OVČINNIKOV AND V. V. DELEKTORSKIJ \\ Department of Microbiology, Central Institute of the Ministry of Health of the USSR for Research on \\ Skin and Venereal Diseases (Director: N. M. Turanov)
}

The causative agents of syphilis, yaws, and pinta are of very similar morphology, and no structural differences between them can be detected on darkfield examination. A number of electron-microscope studies have been made of Treponema pallidum (Pillot, 1965; Ryter and Pillot, 1963; Ovčinnikov and Delektorskij, 1965, 1966, 1968) and it has been shown that the structure of this treponeme is complicated: but studies of Treponema pertenue have so far failed to reveal the elements now known to be present in T. pallidum. An electron-microscope study of $T$. pertenue has therefore been undertaken using negative contrast and ultrathin sections.

\section{Methods}

The material was prepared for examination by the electron microscope in the same way as that used by the authors to study $T$. pallidum: fixation with glutaric aldehyde in phosphate buffer by the method of Sabatini, Bensch, and Barrnett (1963), followed by osmium fixation by the method of Palade (1952) as modified by Fernando and Movat (1964). The material was dehydrated in increasing concentrations of acetone and then embedded in Epon 812 by the method of Luft (1961).

The method used for negative contrast did not differ significantly from that described in our earlier communications (Ovčinnikov and Delektorskij, 1965, 1966, 1967, 1968).

The ultrathin sections were made with an LKB (Sweden) microtome.

The electron-microscope studies were made with a Soviet UEMV 100 A microscope and with a Czechoslovak Tesla 513 BS microscope, resolving power $4.5 \AA$.

\section{Material}

Treponema pertenue was obtained from lesions in rabbits after intratesticular infection or subcutaneous injection into the scrotum. The infecting material was obtained initially from Dr. Vaisman of the Fournier Institute in Paris, to whom the authors are much indebted. The strain was isolated by Dr. Zahra in Brazzaville in 1960 by infecting hamsters with scrapings from a papillomatous site on a 10-year-old child. It had been transferred in hamsters

*WHO/VDT/RES/69.184

Received for publication January 30, 1970 and rabbits, and was received by us in a frozen state on 18 September, 1967. When golden hamsters were infected with it (subcutaneously, in the inguinal fold) there were not as a rule any external symptoms, although motile treponemes, sometimes at the fission stage, were found in the lymph nodes, testes, and spleen.

The rabbits were infected subcutaneously in the scrotum or intratesticularly (as a rule subcutaneously on one side and intratesticularly on the other). Irrespective of the mode of infection, compact nodules smaller than a millet grain appeared on the testicular membranes on both sides. These nodules gradually enlarged and sometimes reached the size of a large cherry and occasionally even of a plum, although they were usually the size of a pea. The nodules were not fused with the skin. There were no marked clinical findings in the testis, but microscopy revealed treponemes. In the lymph nodes they were more plentiful.

For examination under the electron microscope we either used a suspension of treponemes or examined them directly in material from the nodes, especially when ultrathin sections were prepared. Preference was accorded to examination of the treponemes in pieces of tissue from lesions, because they are easily damaged in the preparation of a suspension.

\section{Results}

NEGATIVE CONTRAST

$T$. pertenue obtained from the nodules of lesions on the testicular membranes and treated by the negativecontrast method appears under the electron microscope as a spiral-like structure (Figs 1 and 2) with slightly acuminate ends, and with a bundle of fibrils (F) wound round the body of the treponeme. At each end of the treponeme there is a small area (Figs 3A, $3 B, 4,5)$ where there is a spongy mass $(0)$ surrounded by an outer wall (ME). Beyond it the elongated end is thinner than any part of the body of the treponeme (its length is greater than in T. pallidum). Sometimes the end is not elongated, but flattened and recurved (Fig. 3, details A and B, and Fig. 4); three to six basal granules (B) in the shape of dark rounded structures are situated some distance from the tip (Figs 3A, 3B, $4,5,6)$; these are further apart than in $T$. pallidum. Fibrils (F) originate from each basal granule. The 
number of fibrils does not remain constant along the entire length of the treponeme (there may be three at one end (Fig. 2, F) and four to six in the central portion (Fig. 2)). It must be assumed that the fibrils at the opposite ends of the treponeme are different. They do not extend from one end to the other. When a close structural comparison is made of the ends of $T$. pertenue (Figs 1 and 2), some difference may be noted, although it is not so great as in T. pallidum.

Throughout the entire body there are fairly large layered structures (mesosomes) occupying the whole cross-section of the treponeme or even extending slightly beyond its limits (Figs $1,2,5,8$, and 9, $M$ ). An inner layered structure can be seen in some of them (Figs 2, 8, and 9, $M$ ), others appear merely as a rounded structure (Fig. 1, M), while in yet others the site of the mesosome is surmounted by a tongueshaped process (Fig. 1, M) located beneath the outer wall and having an internal lengthwise cavity. Comparison of $T$. pertenue with cultivated strains of $T$. pallidum shows that the cultivated strains of $T$. pallidum and the Budapest strain of tissue $T$. pallidum have blunter ends.

$T$. pertenue and the Nichols strain of $T$. pallidum have more acuminate ends, and in the case of $T$. pertenue these are longer (Figs 9 and 10). T. pertenue also reveals approximately the same pattern in tissues,

FIG. 1 T. pertenue under the electron

microscope. Negative-contrast method. $\times 11,000$; details $1 A$ and $1 B \times 53,000$. Mesosomes $(\mathrm{M})$ clearly visible

FIG. 2 Same as Fig. $1 . \times 40,000$

FIG. 3 T. pertenue under the electron

microscope. Negative-contrast method. $\times 30,000$.

The ends of the treponeme are dilated and recurved.

This is especially evident in details $3 A$ and $3 B$. $\times 133,000$

FI G. 4 T. pertenue. Negative-contrast. $\times 133,000$.

End of treponeme dilated, shortened, and recurved.

Basal granules clearly visible

F IG. 5 T. pertenue. Negative-contrast. End of

spongy mass dilated. $\times 53,000$

FI G. 6 T. pertenue. Negative-contrast. Long

acuminate end devoid of spongy mass $\times 53,000$ e.g. among collagen fibres (KL), which exhibit clear structural periodicity (Figs 7 and 8 ). Nor does the treponeme show any distinguishing structural feature when it occurs among other elements (Figs 10 and 11).

Whereas it is sometimes possible in the early stages of the development of $T$. pallidum to detect a mucoid substance surrounding the treponeme like a capsule and apparently excreted by the treponeme itself (Ovčinnikov and Delektorskij, 1968), Treponema pertenue has no such 'casing', but merely a narrow band encircling the body of the treponeme.

In a study of the pathology and morphology of materials from lesions arising in yaws and spontaneous spirochaetosis in rabbits, Turner and Hollander $(1950,1954)$ found either that mucoid substance did not accumulate at all or that it was far less abundant than in a syphilitic lesion.

$T$. pertenue multiplies in the same way as $T$. pallidum, by transverse fission. Dividing treponemes may be seen in Figs 12 and 13; there is a distinct 'bridge', apparently nuclear vacuoles, linking the dividing halves, a still-intact outer wall covering both halves of the treponeme, and basal granules (B) on either side of the 'bridge' with fibrils (F) extending from them in opposite directions. The number of fibrils, including the old ones, is ten to twelve (Fig. 12).

FI G. 7 T. pertenue among collagen fibres. $\times 30,000$. Structural periodicity of collagen fibres clearly visible. The number of fibrils is not the same in different parts of the treponeme

FIG. 8 T. pertenue (as Fig. 7) See mesosomes

FIG. 9 T. pertenue. Negative-con $\times 30,000$. Mesosome (M) in central portion

FIG. 10 T. pertenue. Material from a 6-week-old orchitis. $\times 30,000$. The end of the treponeme is sharply acuminate

FIG. 11 T. pertenue (as Fig. 10) The tip is blunt and basal granules begin from the end

FIGS 12 AND 13 T. pertenue. Negative-contrast. Transverse fission. Fig. $12 \times 133,000$. Fig. 13 $\times 60,000$. The features to be seen are an isthmus $(T)$ at the site of fission and basal granules (B) and fibrils (F) each side of the site of fission

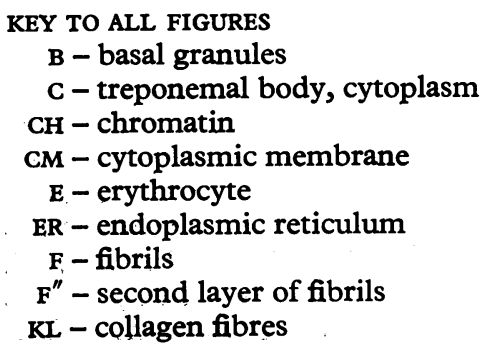

KEY TO ALL FIGURES

CH - chromatin

CM - cytoplasmic membrane

E - erythrocyte

ER - endoplasmic reticulum

F - fibrils

$\mathrm{KI}$ - collagen fibres

$$
\begin{aligned}
& \text { I.I - lipid or fat } \\
& \text { LS - lysosome } \\
& \text { LY - lymphocyte } \\
& \text { M - mesosome } \\
& \text { MC - cell membrane } \\
& \text { MCY - common envelope of cyst } \\
& \text { ME - outer wall } \\
& \text { MI - mitochondria } \\
& \text { MN - nuclear membrane }
\end{aligned}
$$

$$
\begin{aligned}
& \text { N - nucleus } \\
& \text { O - spongy mass } \\
& \text { PC - plasma cell } \\
& \text { PS - pseudopodia } \\
& \text { R - ribosome } \\
& \text { T - site of fission } \\
& \text { TP - Treponema pertenue } \\
& \text { V - microvilli } \\
& \text { ZG - Golgi zone }
\end{aligned}
$$



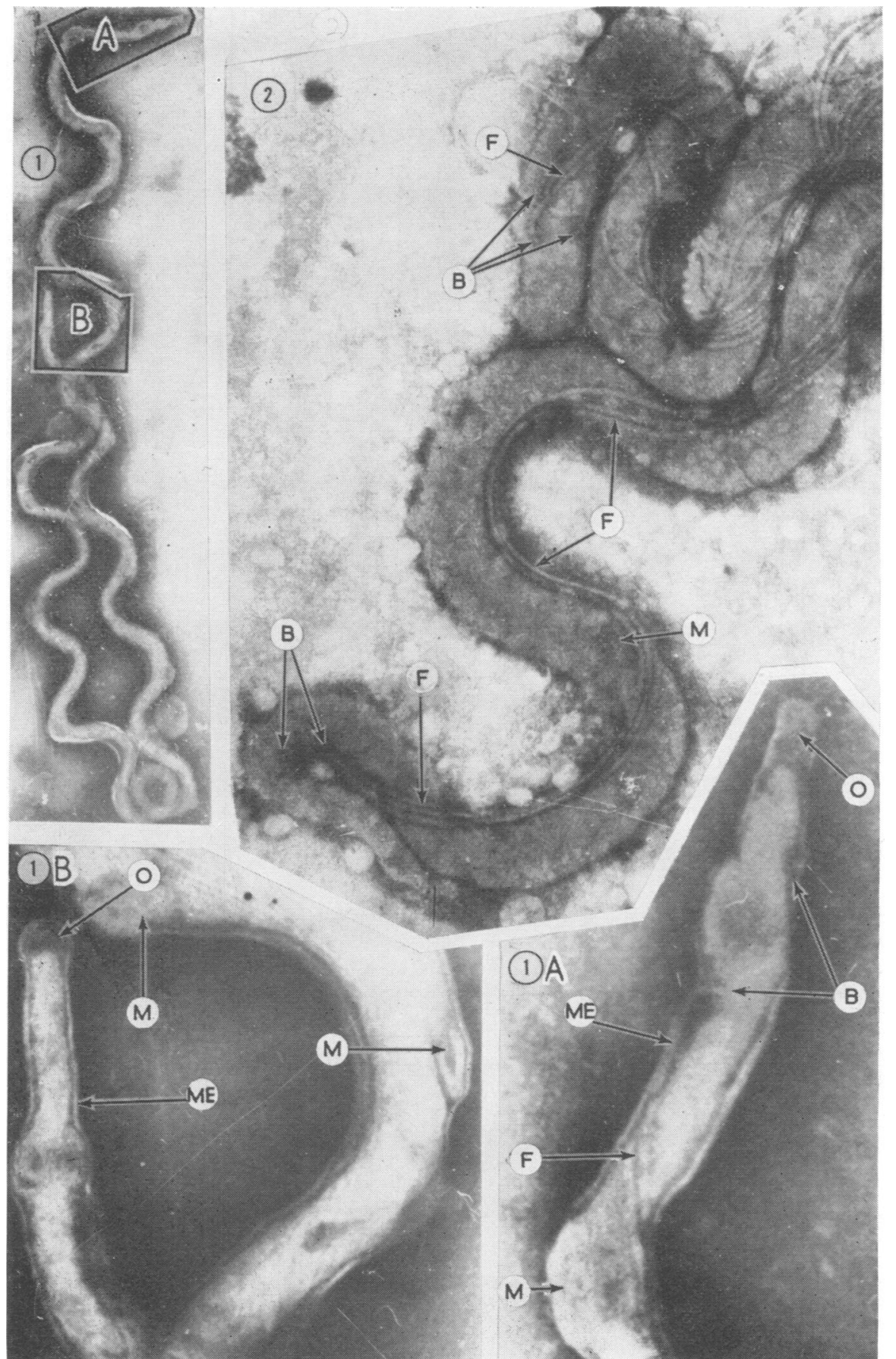

$8 \stackrel{0}{0}$

웅 흘 일 


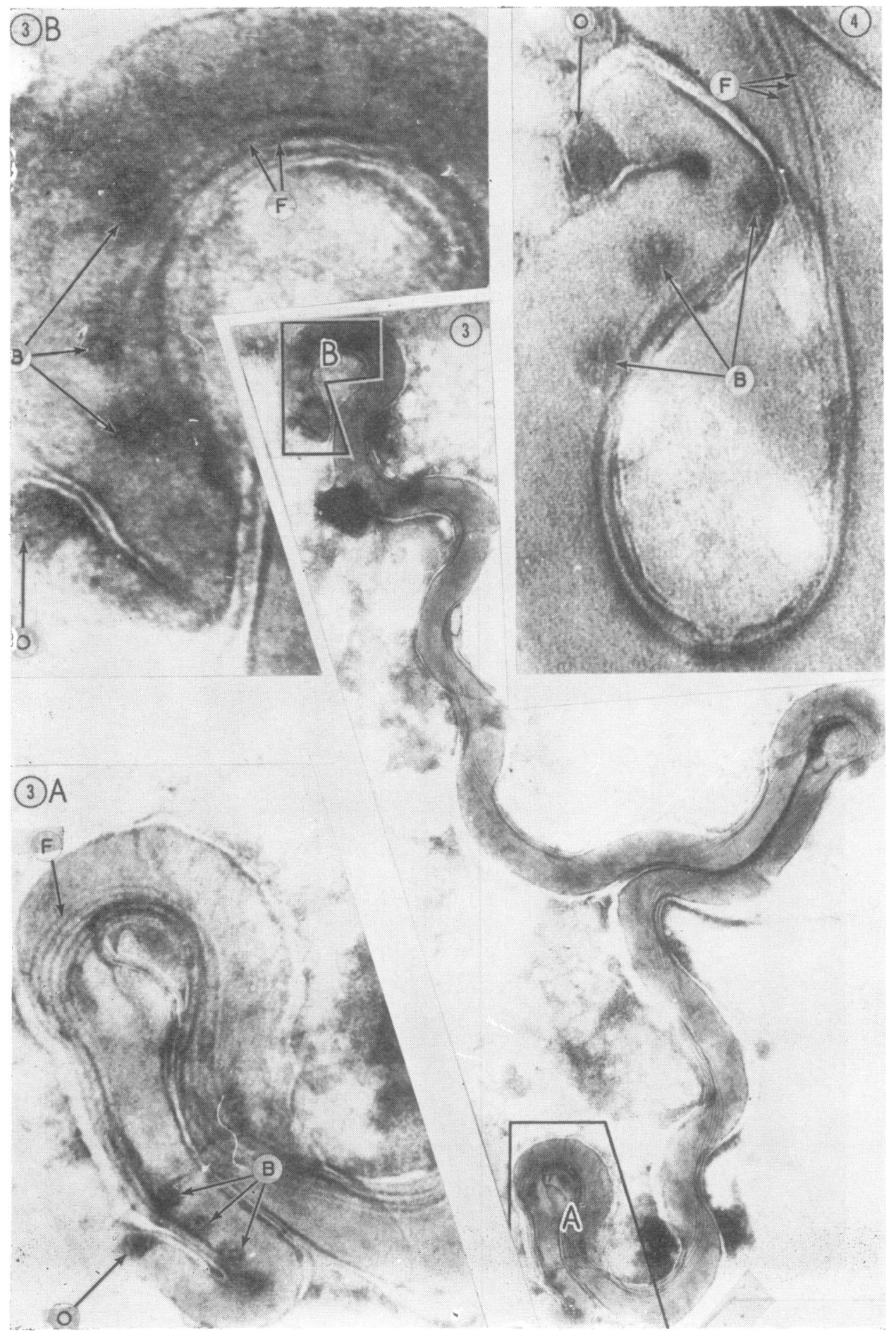


(6)

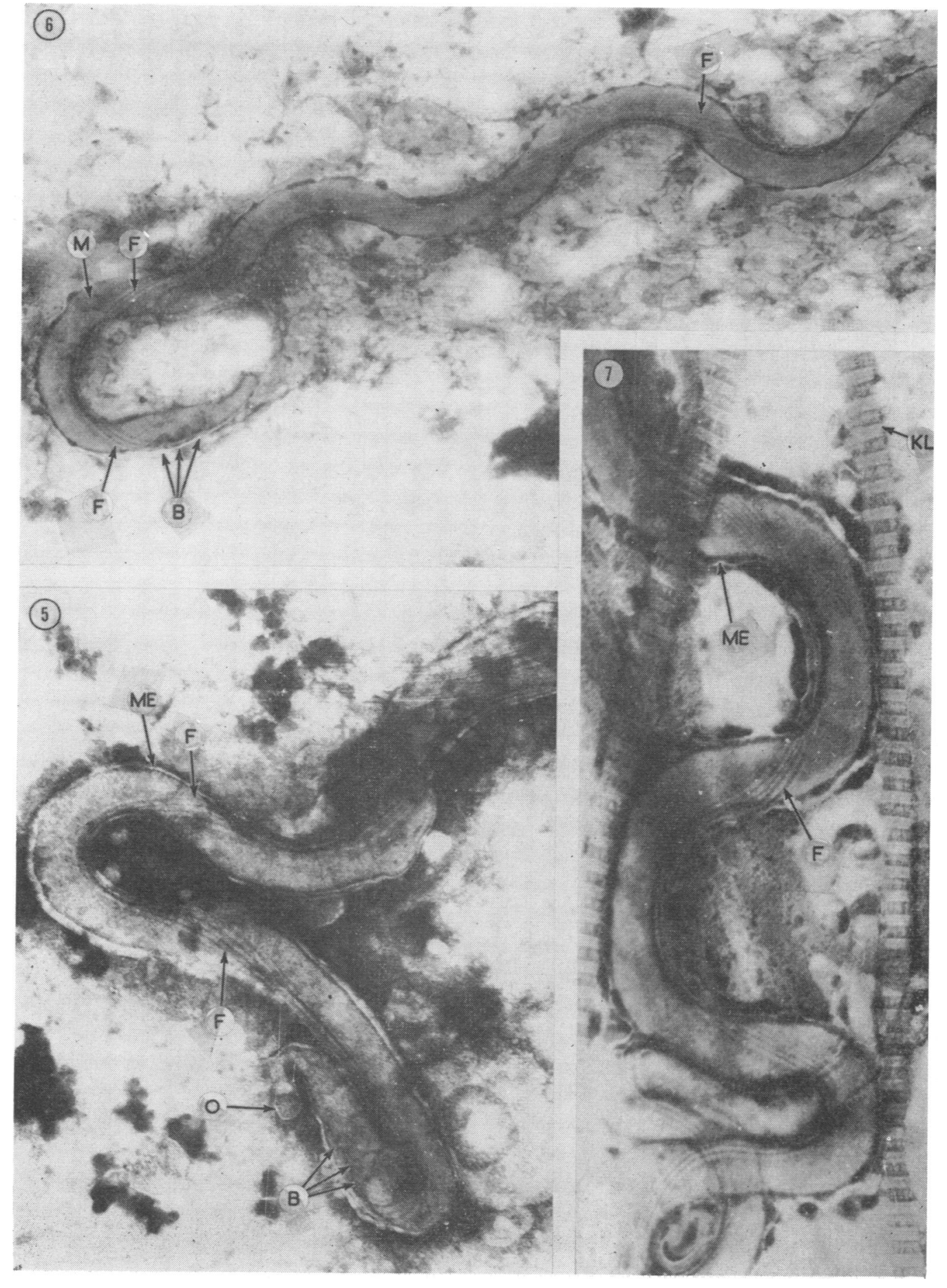



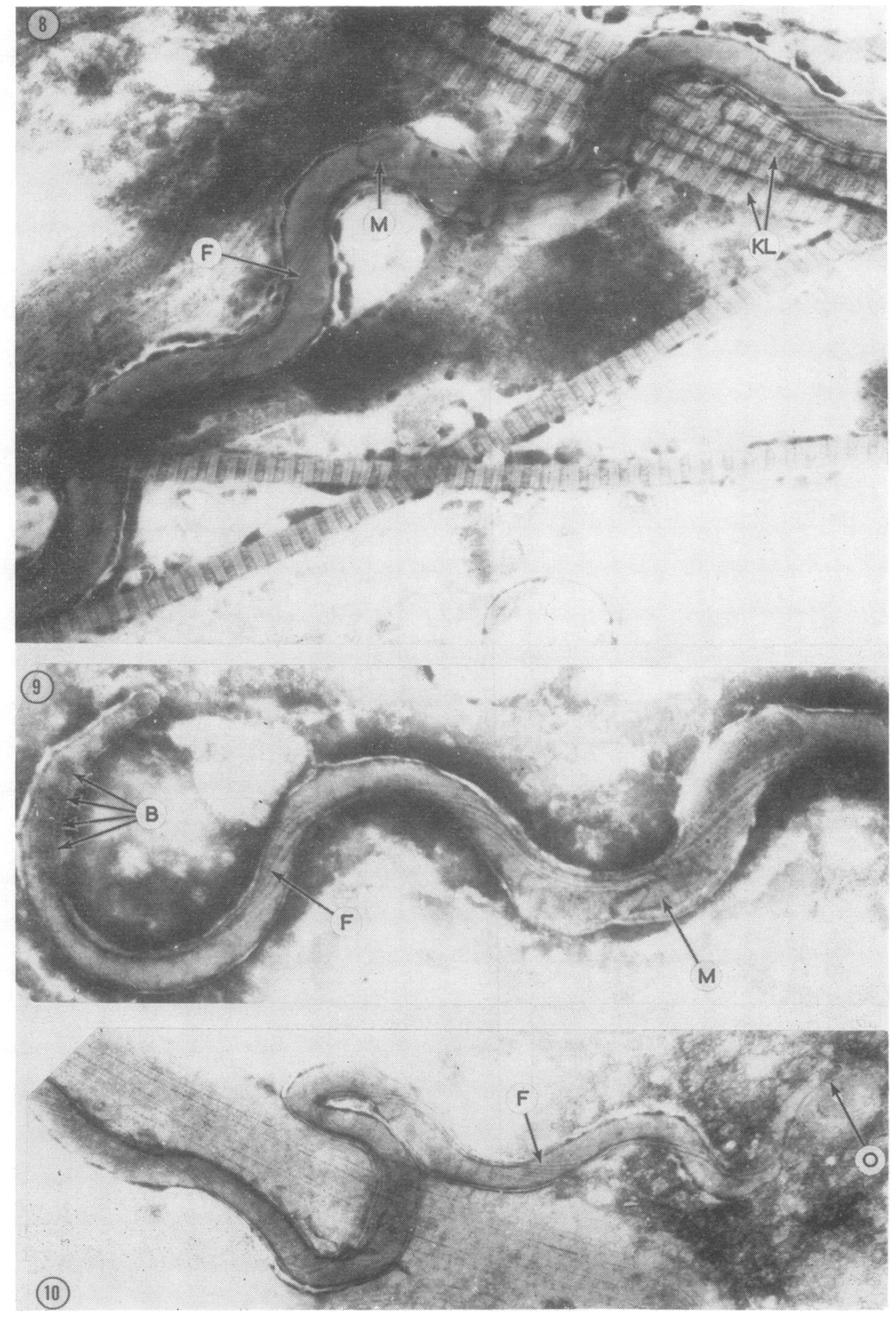

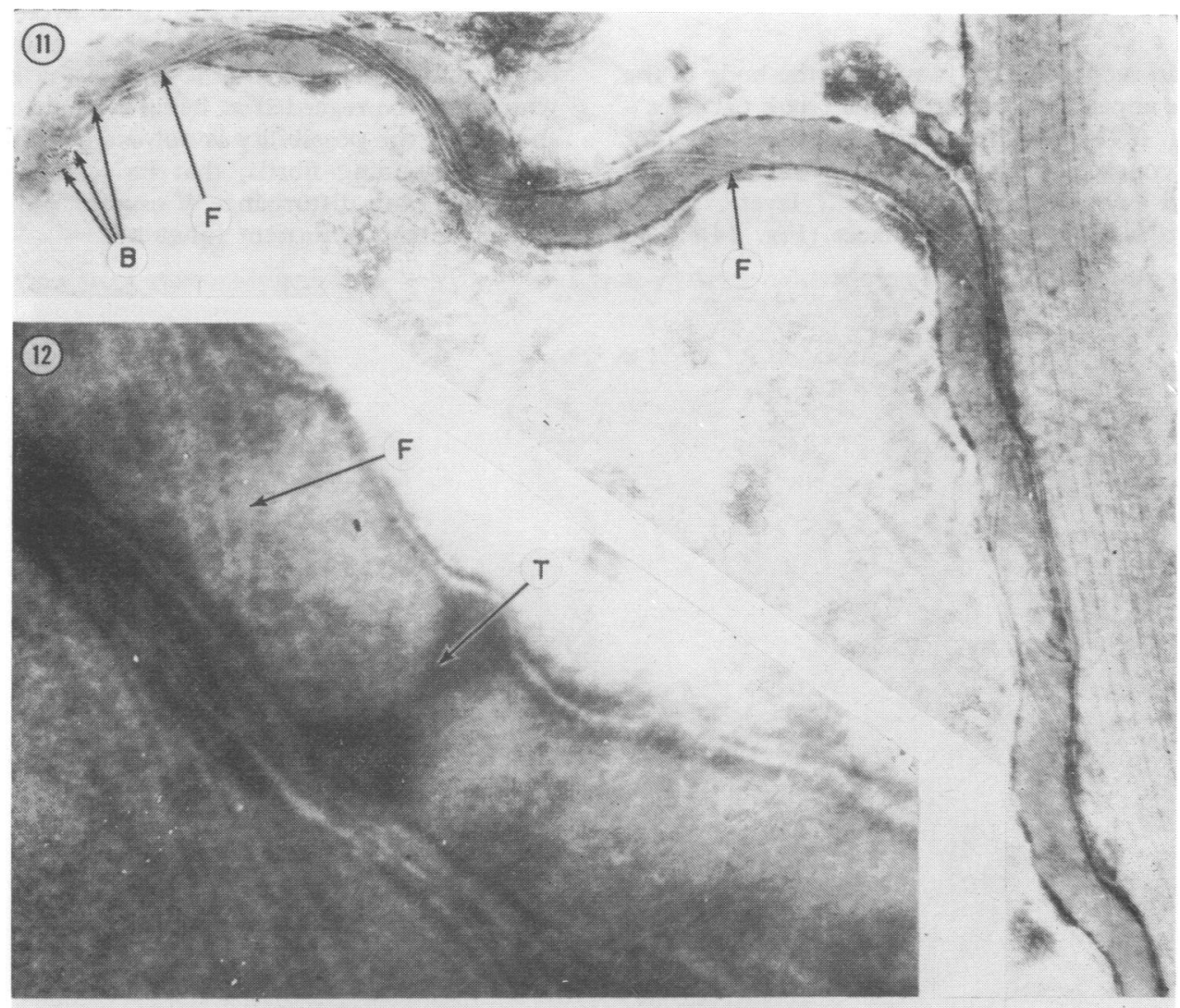

(13)

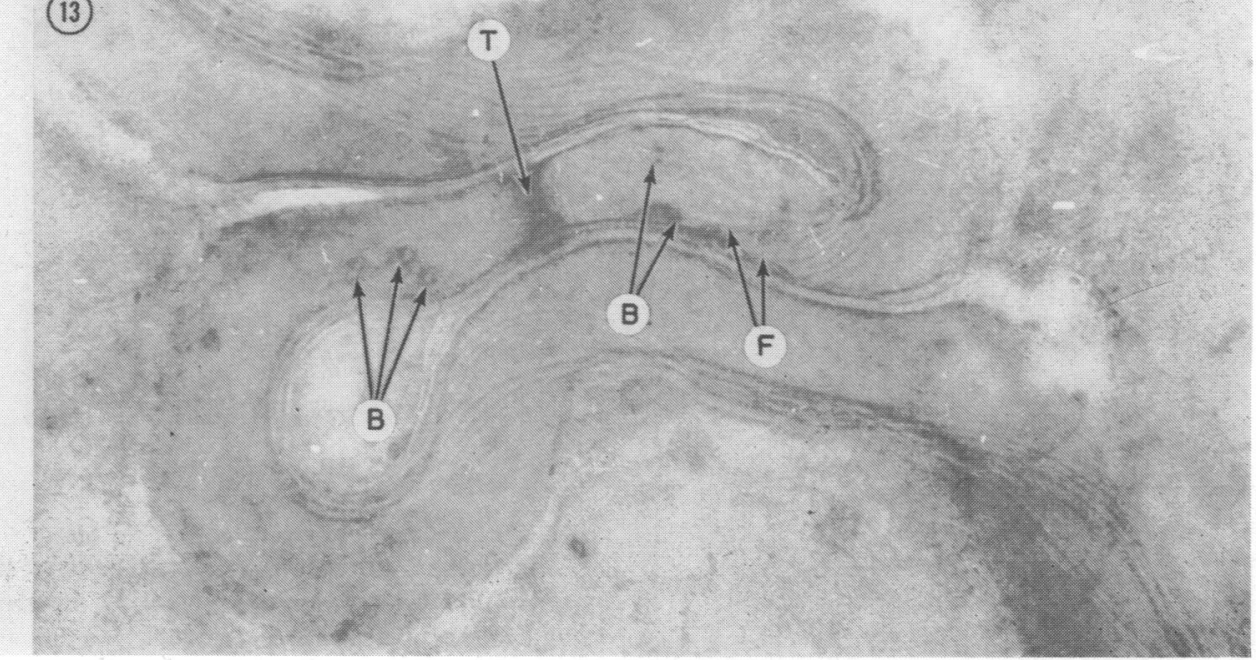




\section{ULTRATHIN SECTIONS}

In ultrathin sections (Figs 14 and 15) the body of the treponeme appears to consist of small dark particles ribosomes (R) - and small light areas. The outer wall (ME) consists of three layers (two electron dense layers and one electron transparent layer), but it appears to be duplicated in places (Fig. 14). The cytoplasmic membrane is also three-layered and fits closely to the cytoplasm. There is a light space between the outer wall and the cytoplasmic membrane which may be regarded as being a result of osmotic shock, but the possibility is not excluded that it is a cavity containing fibrils, that its formation is unconnected with disturbance of osmotic pressure, and that it contains a nutrient substrate.

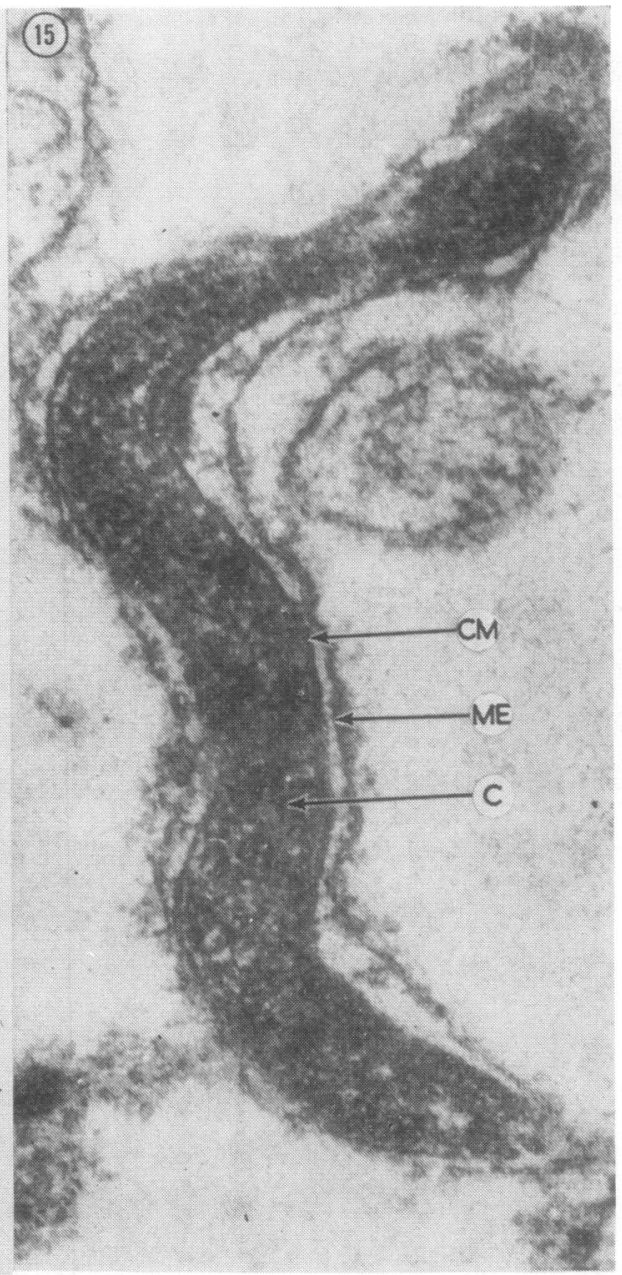

FIG. 14 Longitudinal ultrathin section of $\mathrm{T}$. pertenue. $\times 113,000$. The three-layered structure of the outer wall (ME) and cytoplasmic membrane (CM) and ribosomes $(\mathrm{R})$ are clearly visible

FIG. 15 Same as Fig. 14. $\times 67,000$

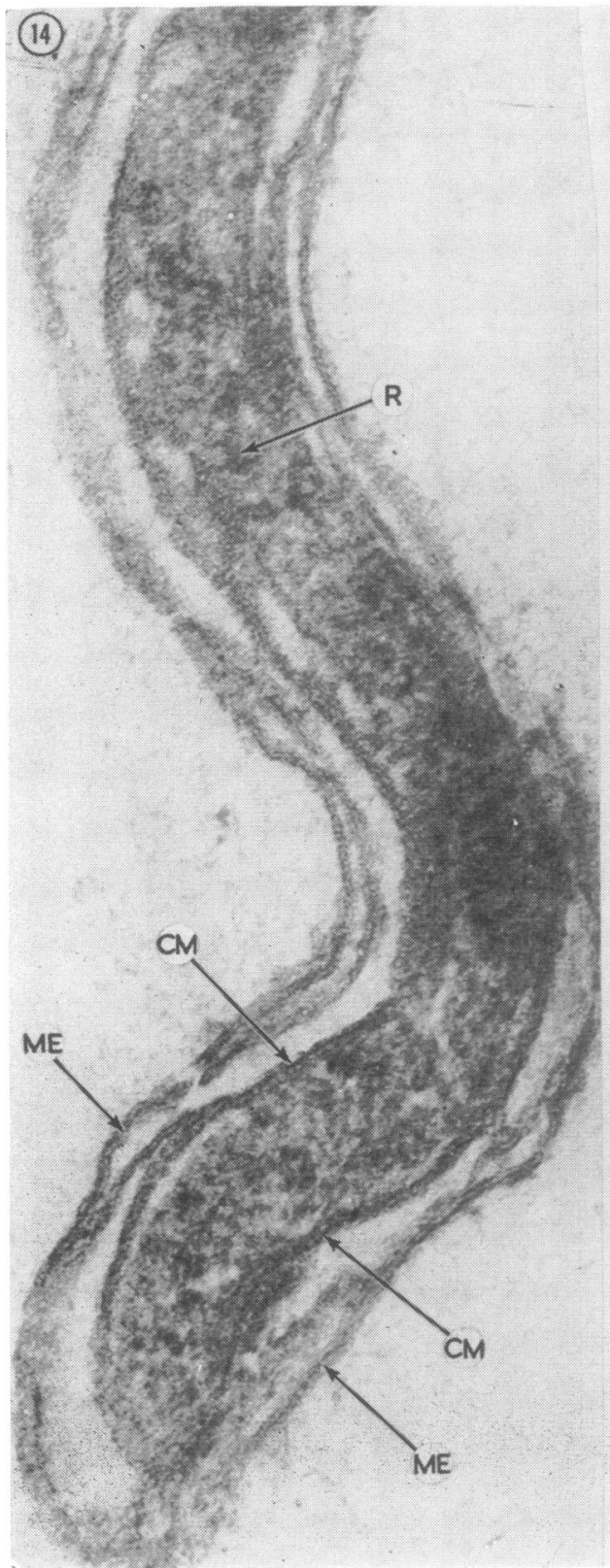


Cross-sections (Figs 16 to 21) show the outer wall and the fibrils. The latter, which appear as three to six rounded structures, often have no outer wall over them and seem to be attached to the cytoplasmic membrane, which is in direct contact with the cytoplasm, or lying free. There is, in fact, an outer wall over them, as is apparent from Figs 19, 20, and 21, but it is evidently very fragile and easily destroyed. Above the cytoplasmic membrane at the level of the fibrillar bundle there are five or six smaller, slightly elongated structures, which apparently comprise the deep fibrillar layer. The body of the treponeme contains osmiophilic granules (ribosomes) and sometimes small polygonal cavities with no membrane (nuclear vacuoles).

When $T$. pertenue is processed by the osmoticshock method and then subjected to differential centrifugation in a saccharose density gradient, a bundle of finer fibrils $\left(F^{\prime \prime}\right)$ may be seen clearly in addition to the thick fibrillar layer (Fig. 22). It is at present impossible to say what precisely these fibrils are, whether they are a second fibrillar layer providing some other forms of motion, whether they have skeletal supporting functions, or whether they have some other significance, but it is most probable that they form a deeper fibrillar layer. The disposition of the surface and deep fibrillar layers relative to the other parts of the treponeme may be seen clearly in cross-sections.

In tissues obtained from lesions, $T$. pertenue may be seen under the electron microscope to be outside some cells and inside others. In Figs 23, 24, 25, 26, and 27, the treponeme may be seen in the intercellular spaces, which are so distended that most of the cells appear to be isolated from each other; the paravascular spaces are particularly distended (Fig. 28, and the detail 28A). Treponemes are usually quite plentiful in these spaces. Fig. 28 shows a blood vessel enclosing an erythrocyte with a well-defined membrane. The surfaces of two endothelial cells in close apposition create the impression of a duct extending from the blood vessel into the paravascular space. Two microvilli project into the vessel. On the outside of these endothelial cells there is a large space containing a lymphocyte and a plasma cell with a well-defined endoplasmic reticulum. Rabbit chancres are most often found to contain lymphocytes, plasma cells, macrophages, and connective-tissue cells. The elements and features clearly distinguishable in the plasma cells include a well-developed endoplasmic reticulum, mitochondria, Golgi zone, and ribosomes (Figs 29 and 29A). The treponeme may retain all its structural features in the intercellular spaces; the outer wall may be in close contact with the cytoplasmic membrane or there may appear to be a three-layered 'casing' around the treponeme at some distance from its body. Both forms of treponeme may be found in the same microscopic field. What is the nature of this phenomenon? It might be assumed that it was the outer wall split into layers by osmotic shock, but in that case similar changes should be found in the other treponemes, but are not. Could it be a protective membrane? In some cases it is a protective membrane, since the treponeme also has an outer wall and a cytoplasmic membrane (Fig. 23). This may also be seen in Figs 24 and 25.

FIGS 16 AND 17 Cross-section of T. pertenue. $\times 100,000$. Outer wall destroyed over the fibrils

FIG. $18 \times 53,000$

FIGS 19 AND $20 \times 67,000$

FIG. $21 \times 100,000$

In Figs 18 to 21 the outer wall (ME) is intact over the outer fibrillar layer (F); the cytoplasmic membrane (CM) and the deep fibrillar layer $\left(\mathrm{F}^{\prime \prime}\right)$ are clearly visible

FIG. $22 \times 100,000$. T. pertenue processed by the osmotic-shock method followed by differential centrifugation in a saccharose density gradient. $A$ surface layer of thick fibrils (F) and a deep layer of fine fibrils $\left(\mathrm{F}^{\prime \prime}\right)$ are visible. Insertion on the basal granule is clearly visible in the case of one of the fibrils. The fibrils of the deep layer do not extend to the basal granules

FIGS 23, 24, AND 25 Ultrathin section of $T$. pertenue in intercellular spaces. The section of material from a lesion on the testicular membranes. $\times 30,000$. Triple layering of outer wall (ME) clearly visible

FIG. 26 Same as Fig. 23. $\times 7,000$. Details $26 A$ and $26 B . \times 21,000$. Three-layered outer wall clearly visible. Mitochondria (MI) endoplasmic reticulum (ER), and lysosomes (LS) are seen in the cells in Fig. $26 B$

FIG. 27 Ultrathin section of a treponeme (TP) in an intercellular space. $\times 30,000$. Treponemes surrounded by a three-layered 'casing' and others without a 'casing' are seen in the same microscopic field. Outer wall of the treponemes (ME) is intact

FIG. 28 Treponeme in intercellular space. Section through a blood vessel. $\times 6,700$. Detail $28 A$ $\times 23,000$. E - erythrocyte, MC - cell membrane, MI - mitochondria, ER - endoplasmic reticulum, $\mathrm{v}$ - microvilli within the blood vessel, $\mathrm{PC}$ - plasma cell, LY - lymphocyte, $\mathrm{N}$ - nucleus, $\mathrm{CH}$ - chromatin, $\mathrm{MC}$ - cell membrane 

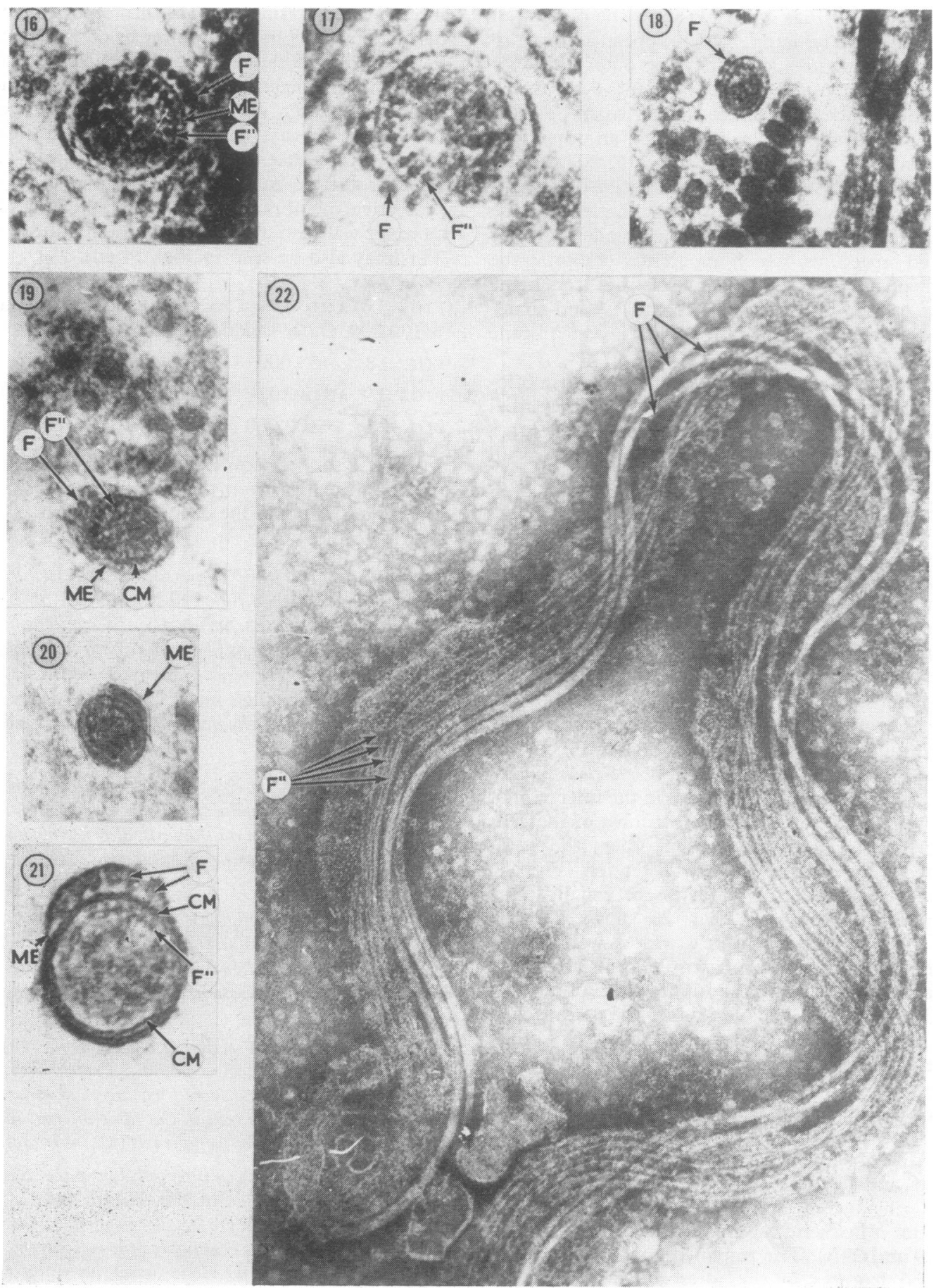
(23)
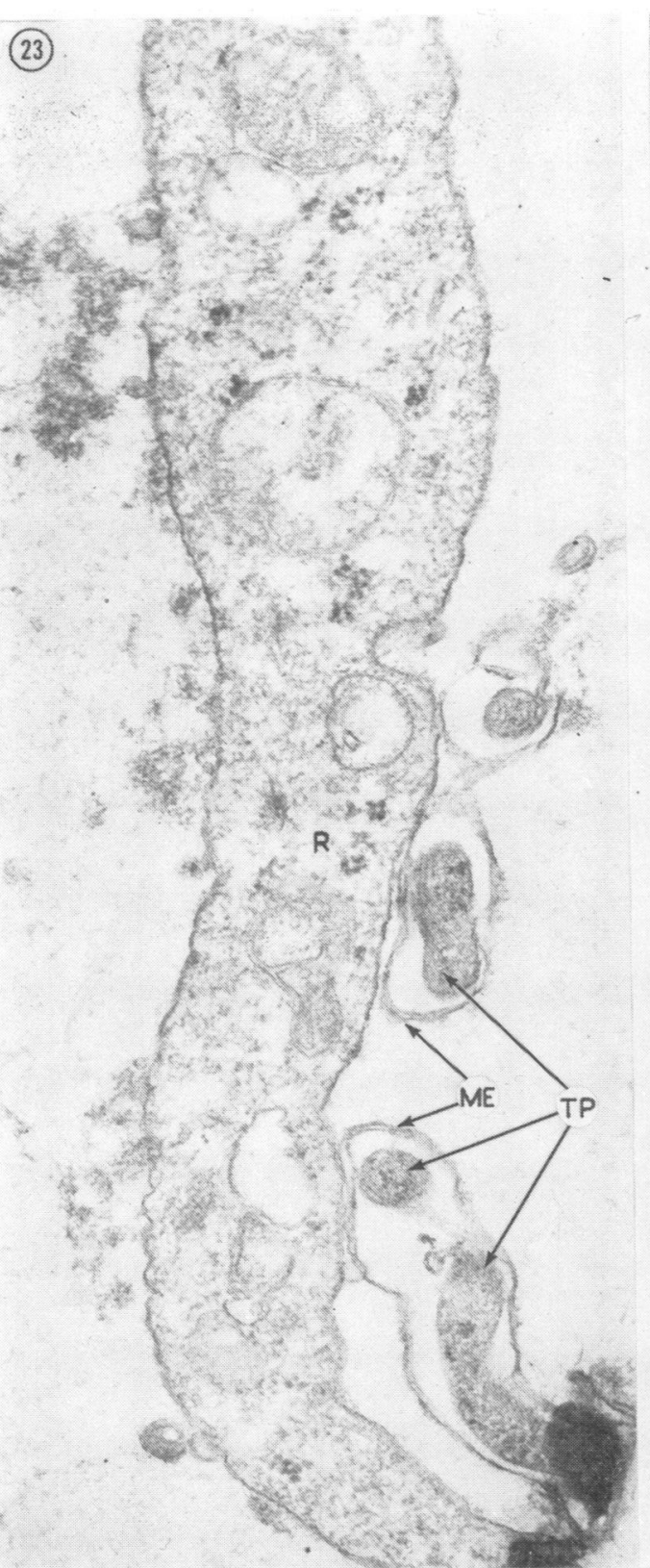
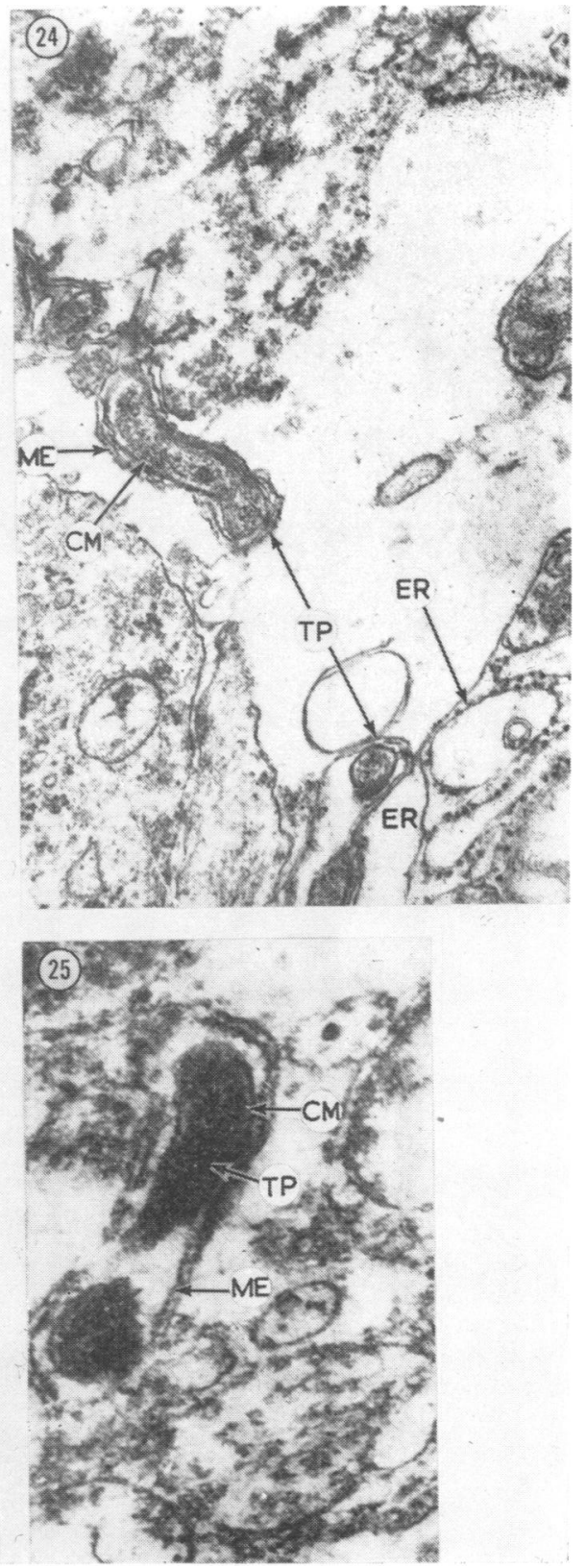

$\underline{\square}$

疍

$\overrightarrow{\overrightarrow{0}}$

읃

$\frac{\bar{\sigma}}{\frac{0}{\sigma}}$

()

$\overrightarrow{0}$

$\overrightarrow{\vec{\omega}}$

$\stackrel{0}{=}$

के

$\stackrel{\omega}{\omega}$

0

윽

0
$\stackrel{9}{0}$
$\stackrel{0}{0}$
$\mathbb{1}$

을. 

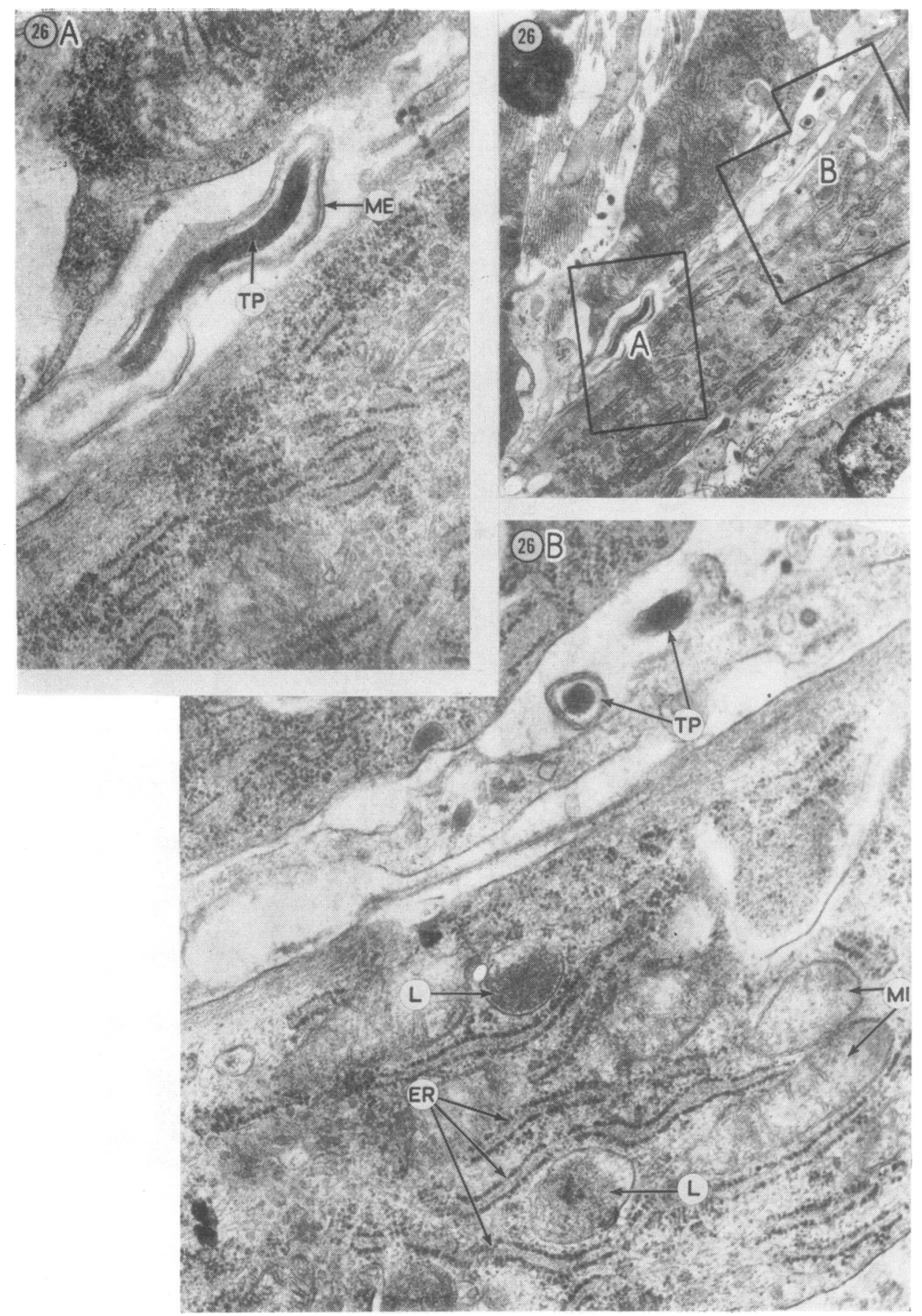


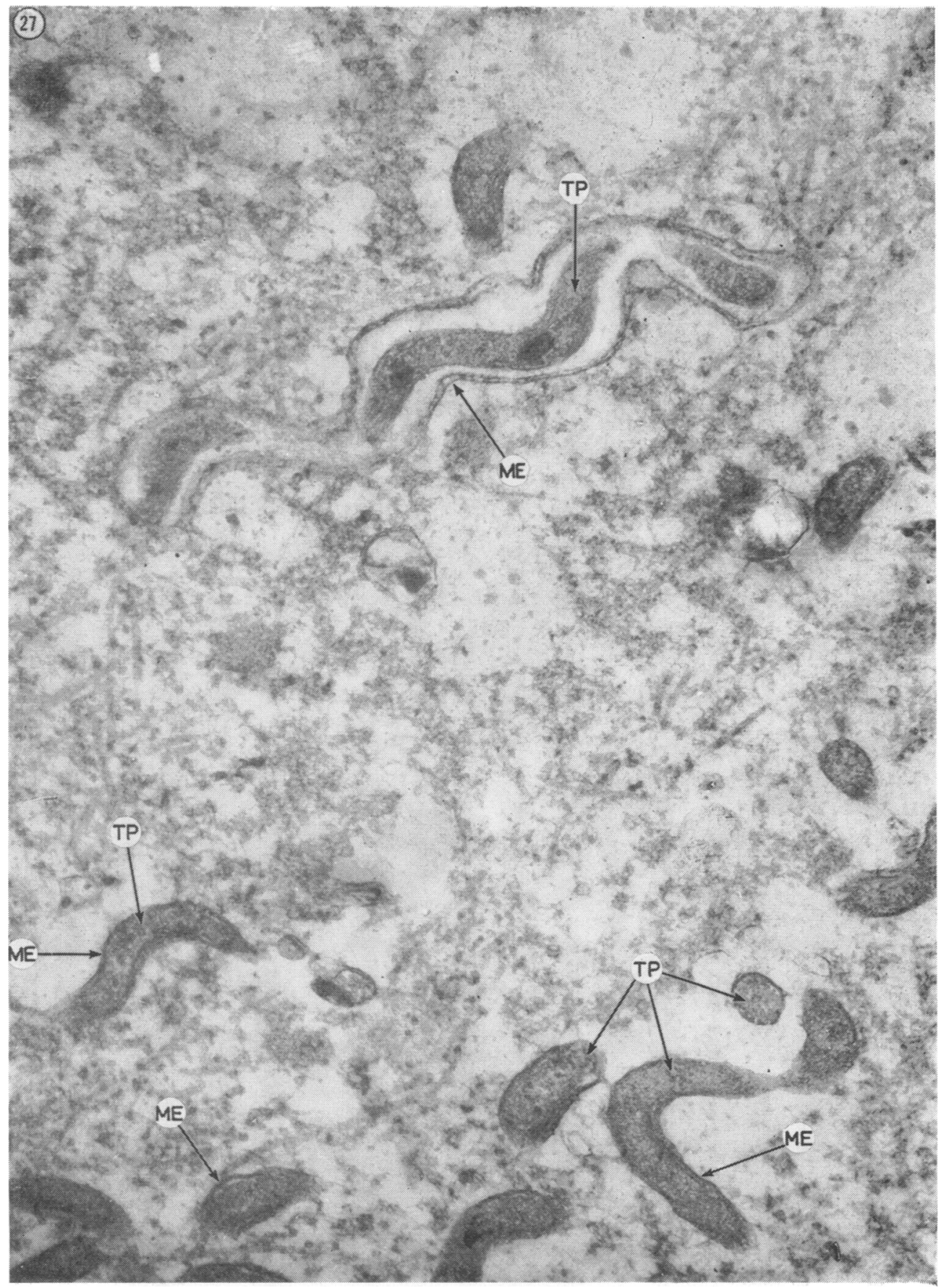



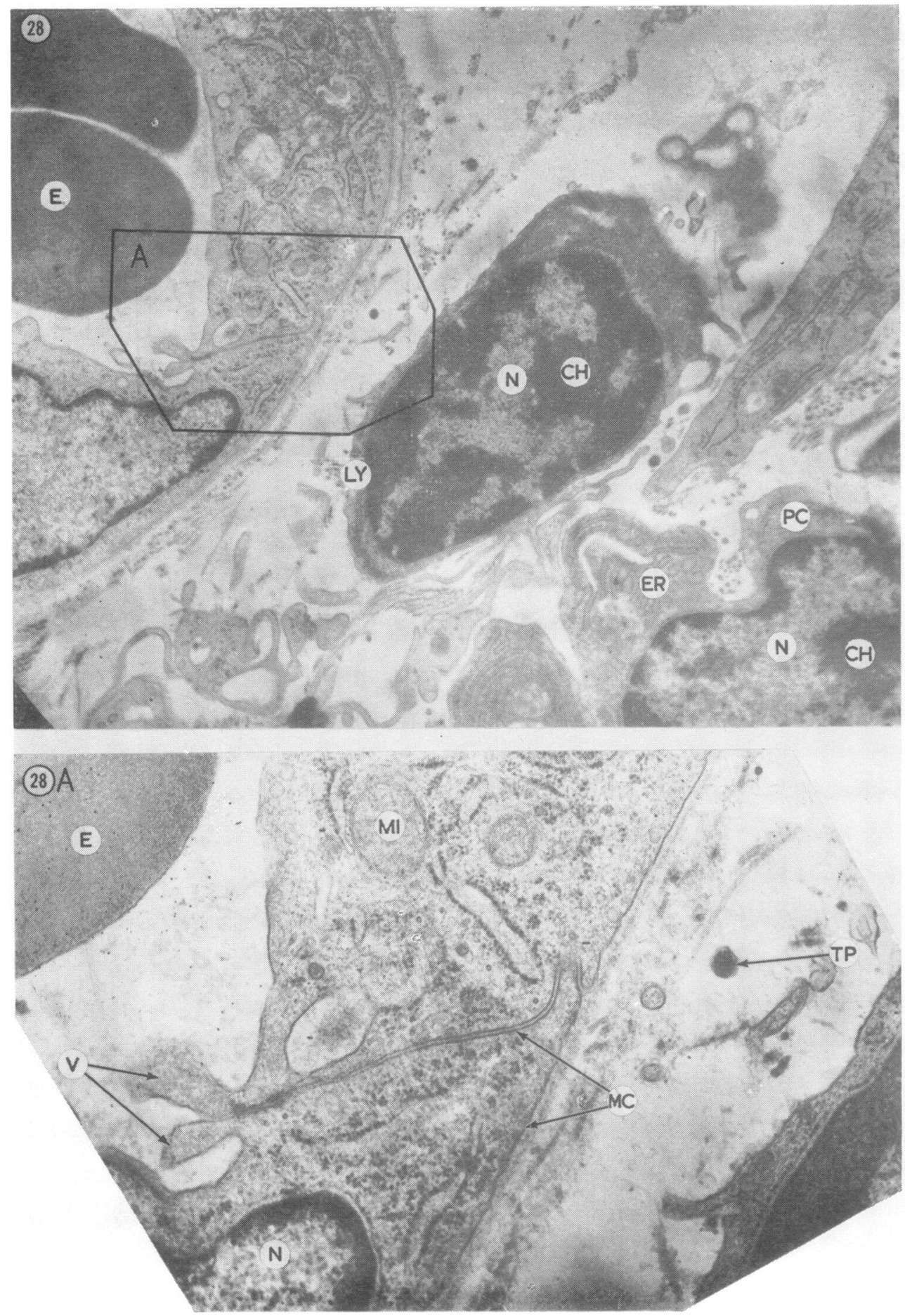
A 'casing' of this type is most often found around destroyed cells among cell debris (Fig. 30), but treponemes may be present without this 'casing' and may still retain their fibrils and ribosomal apparatus. Treponemes may sometimes be very plentiful in the intercellular spaces.
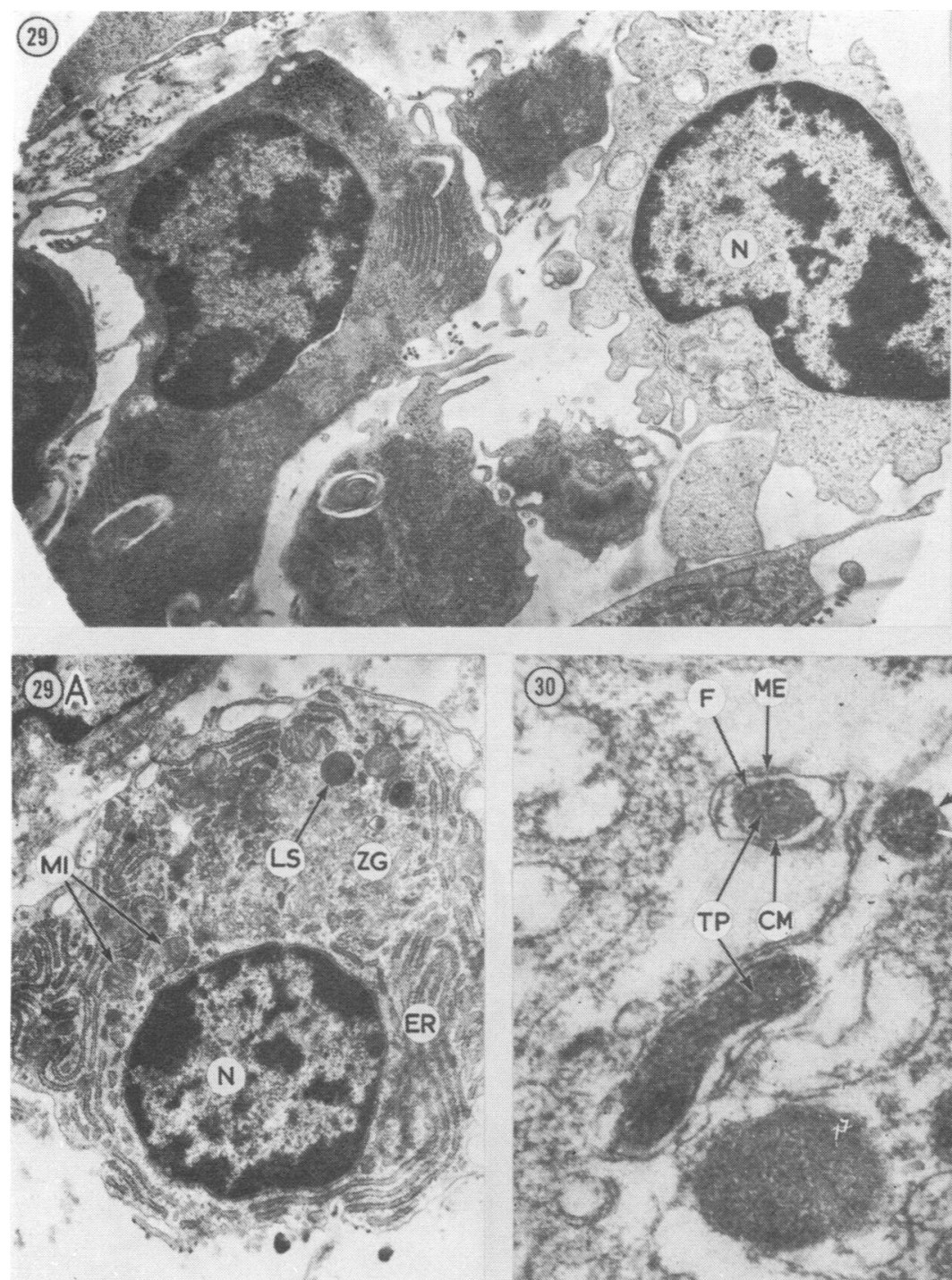

FI G. 29 Section of plasma cell from rabbit chancre. $\mathrm{N}$ - nucleus, $\mathrm{ER}$ - endoplasmic reticulum, MI - mitochondria, $\mathrm{ZG}$ - Golgi zones, LS - lysosome, $\mathrm{CH}-$ chromatin. $\times 7,200$. Detail $29 A \times 12,000$

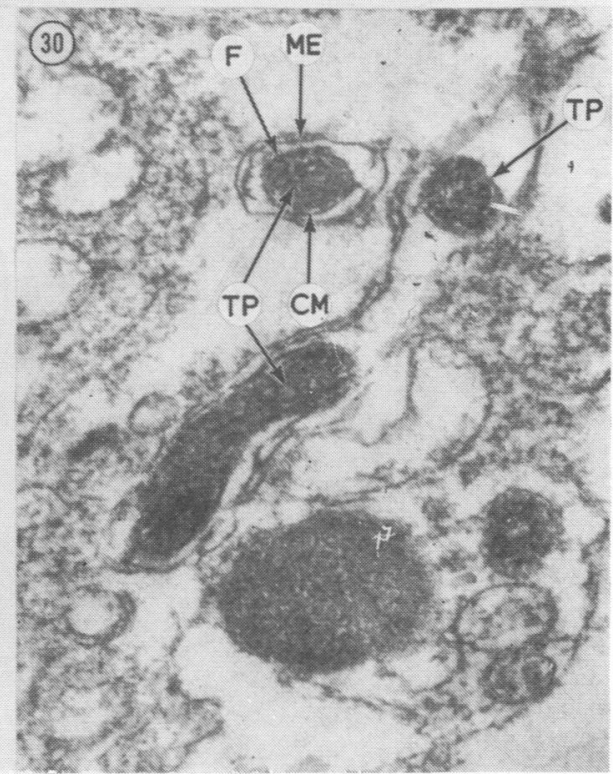
$\times 30,000$. The membranes and the structure of the treponemes appear to be in a 'casing' 
Treponemes may be seen clearly in the intercellular spaces in Figs 31 and 32, and also in the cell cytoplasm in Fig. 33. Their structure is intact whether they are inside or outside the $\mathrm{c}: 11$.

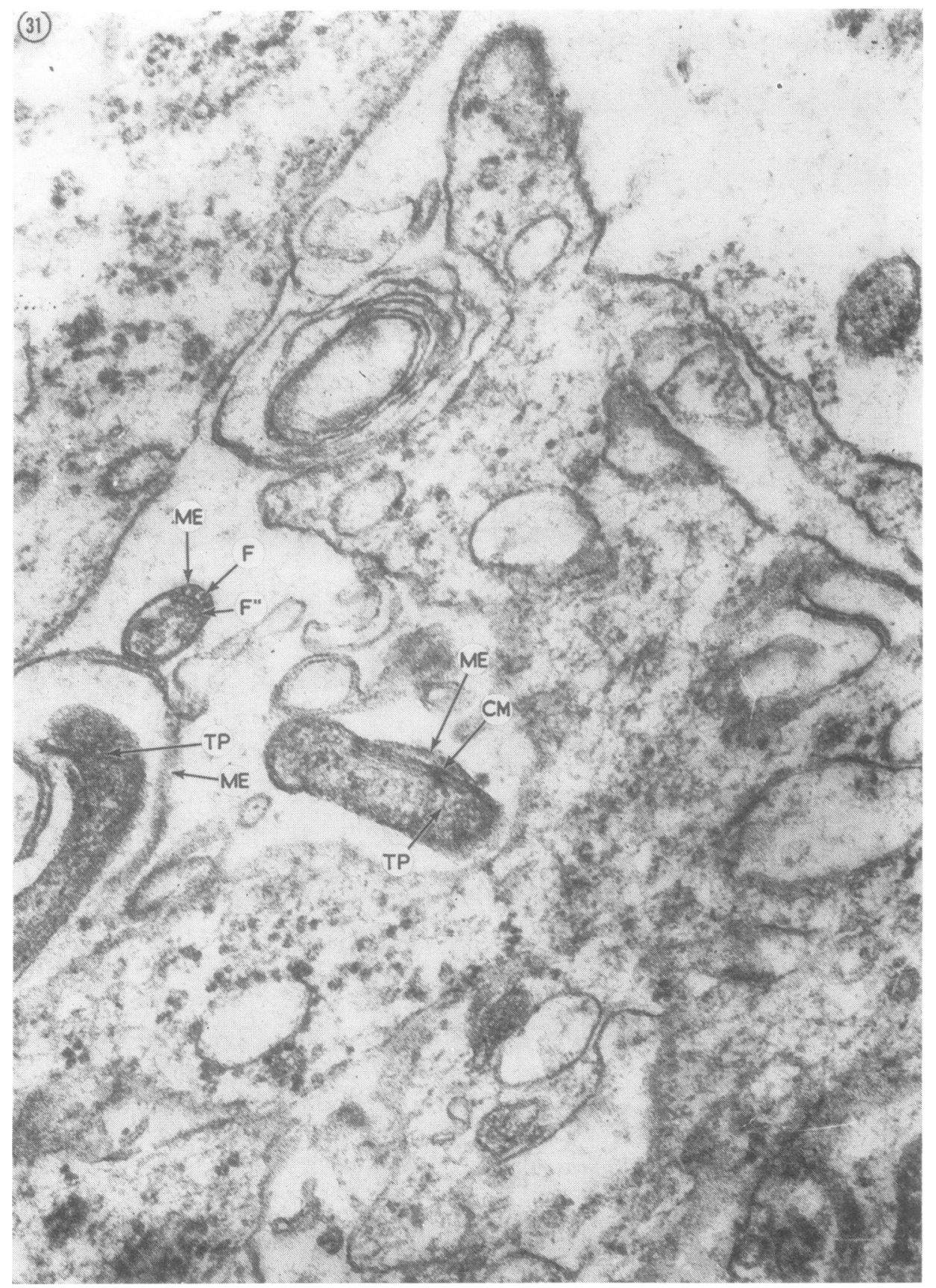

FI G. 31 All the membranes of the treponeme are visible; the surface and deep fibrils are clearly outlined in the cross-section; the outer-wall of one treponeme has moved away from the body. $\times 40,000$ 

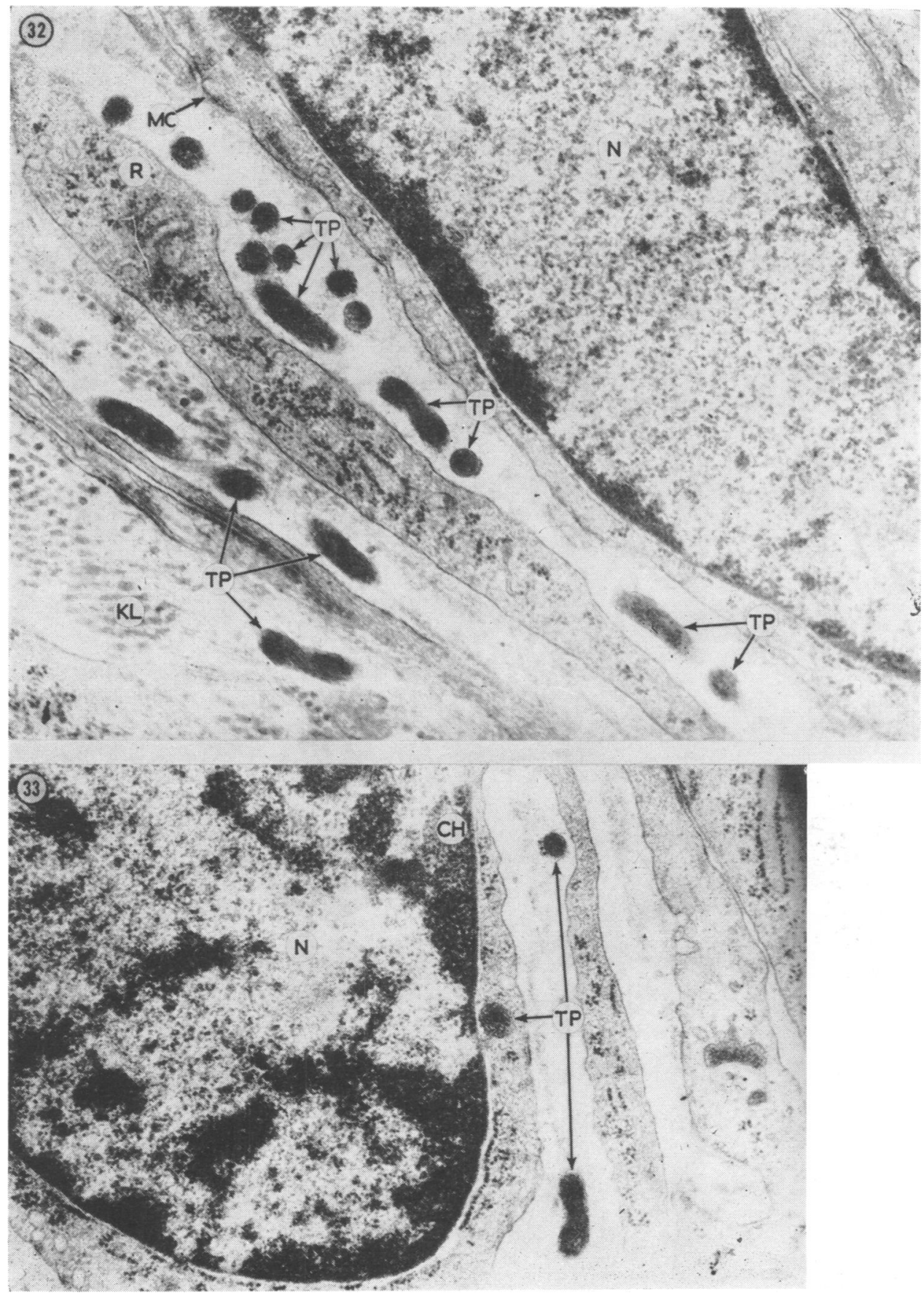

FIGS 32 AND 33 Section of T. pertenue in an intercellular space. The structure of the treponeme is intact. $\times 20,000$. Fig. 33 shows a treponeme in the cell cytoplasm. The cells can be seen to contain a nucleus $(\mathrm{N})$ with chromatin $(\mathrm{CH})$ along the periphery and ribosomes ( $\mathrm{R}$ ) 
Figure 34 shows treponemes inside cells; the one in cross-section is apparently in a lysosome and its structure is indistinct (Fig. 34A - detail).
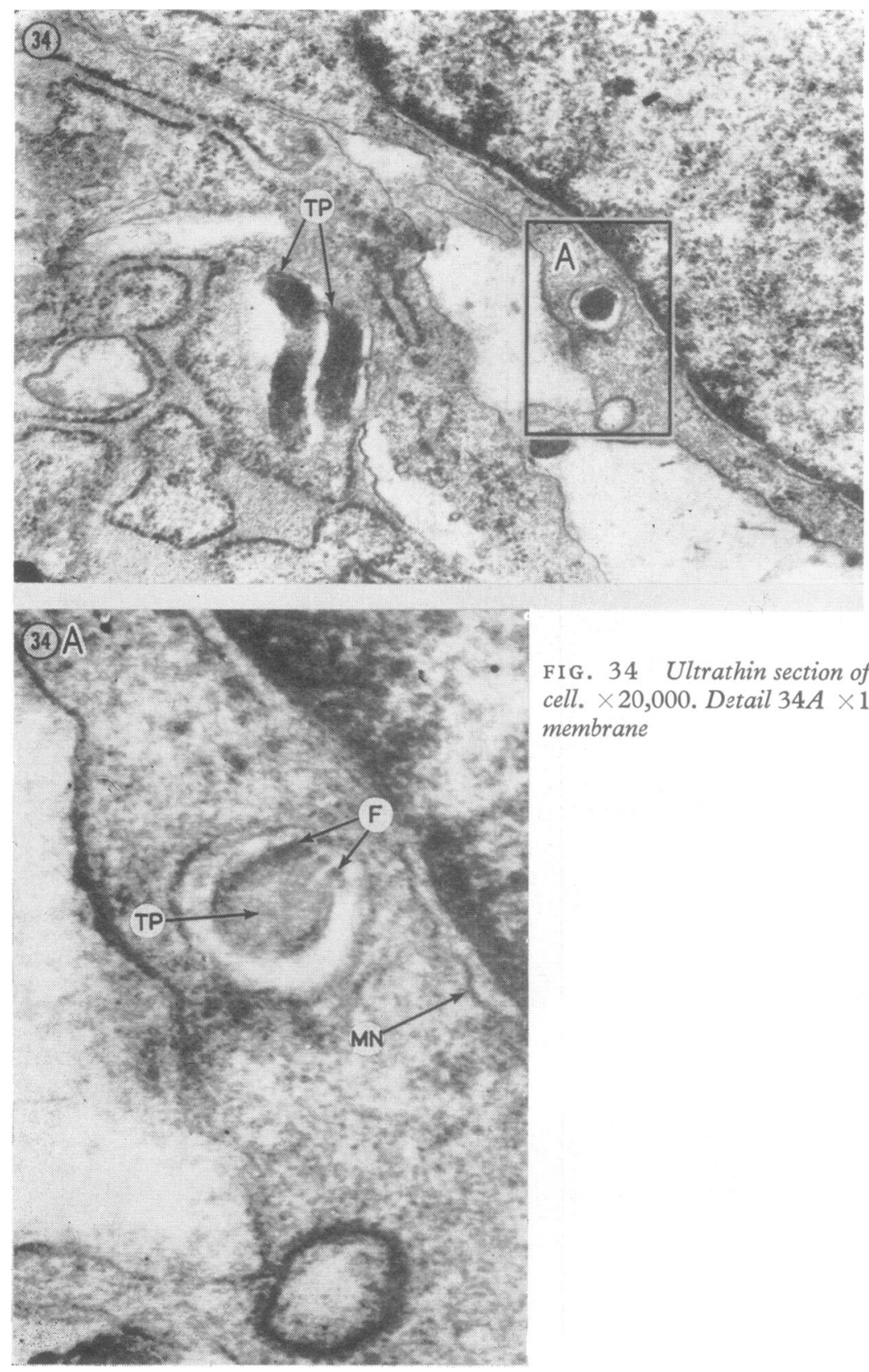

FIG. 34 Ultrathin section of $\mathrm{T}$. pertenue in a cell. $\times 20,000$. Detail $34 A \times 100,000 . \mathrm{MN}-$ nuclear membrane 


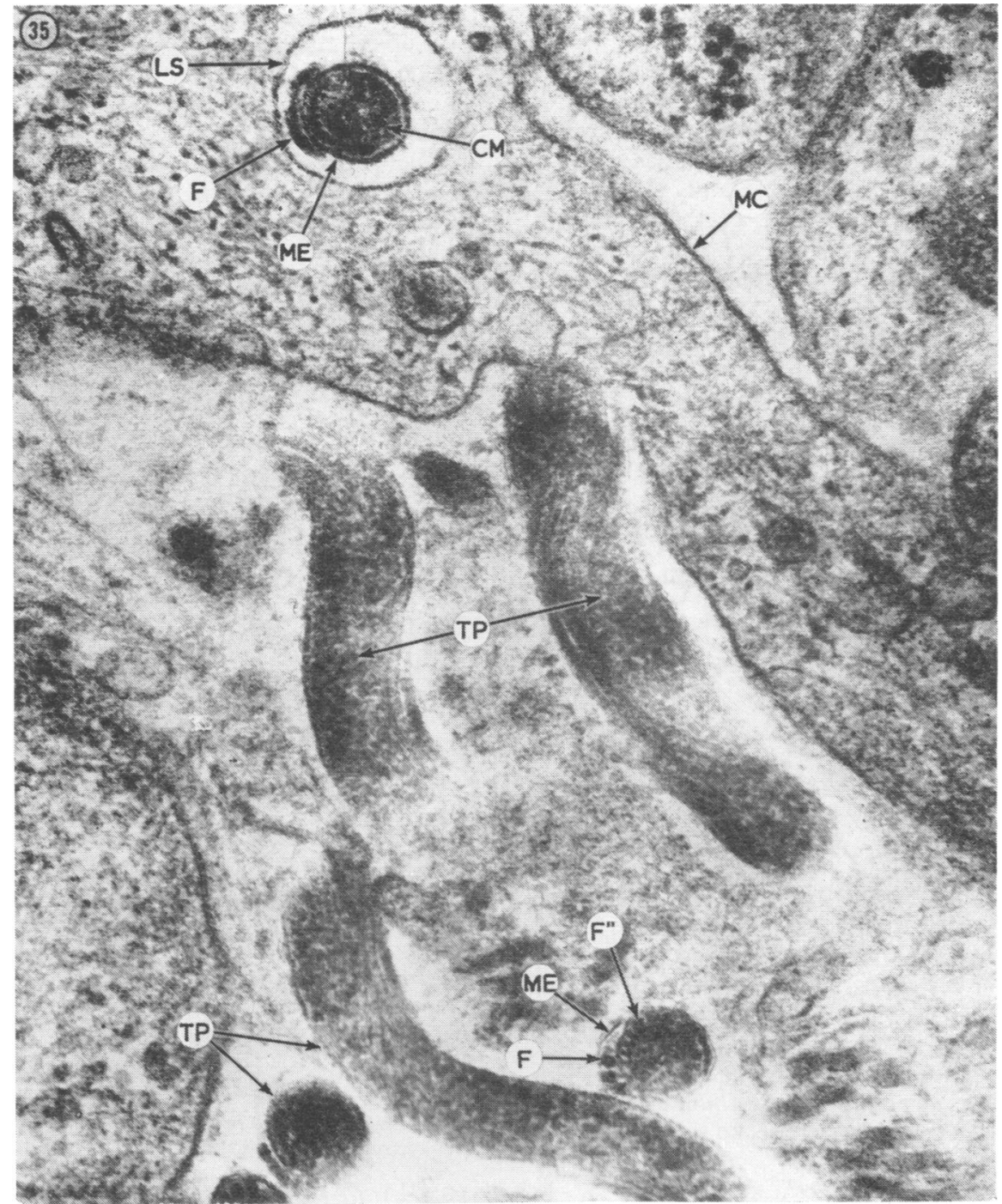

In Fig. 35 treponemes are also present both in the intercellular space and in the cytoplasm of a cell, apparently a lysosome, the walls of which are clearly visible. The structure of the treponeme is intact inside and outside the cells.
FIG. 35 Ultrathin section of $\mathrm{T}$. pertenue in tissue from node on testicular membrane of a rabbit. The structure of the treponemes is intact both in the intercellular spaces and in a lysosome (LS). $\times 67,000$ 
The treponeme enters the cell by pinocytosis (Figs 36 and 36A - detail). The walls of the pinosome are still unclosed and are thick. It is difficult to decide whether the treponeme is inside the lysosome, or whether what can be seen is the protective membrane of the treponeme itself (Fig. 37). The cell has a clearly defined membrane; the elements plainly seen in the cytoplasm are the Golgi zone (ZG), a cell nucleus with chromatin along its periphery, and a nucleus (N) separated from the cytoplasm by a nuclear membrane (MN).

In Fig. 38, a treponeme inside a cell is surrounded by three electron dense and two electron transparent layers. The ribosomes and endoplasmic reticulum alongside play no part in combating the treponeme. A longitudinally-sectioned treponeme to be seen inside a cell in Fig. 39 has a well-preserved ribosomal apparatus and basal granule, and fibrils which are well defined in longitudinal section and cross-section. In places a thick membrane (ME) may be traced enclosing both treponemes at some distance from their bodies. A part of the membrane is close up to endoplasmic reticulum (ER) with clearly distinguishable ribosomes. The same treponeme sectioned in a different plane is shown in Fig. 39A. The pattern is similar to that depicted in Fig. 39, but the basal granule has not been incorporated in the section. There is the same pattern in Figs 40, 41, 42, and 43. The structure of the treponeme can be seen with particular clarity both in cross-section and in longitudinal section in Fig. 41. The structure of the treponemes depicted in Figs 44 and 45 is intact both in a lysosome (Fig. 44) and in a pinosome (Fig. 45). Mitochondria with cristae and a membrane, large nuclei, and long pseudopodia are clearly visible in the cells.

Like $T$. pallidum, $T$. pertenue may also occur in the walls of blood vessels (Figs 46, 47, and 47A) and even in the lumen of a blood vessel and still retain all its structural features.
FIG. 36 Ultrathin section of $\mathrm{T}$. pertenue. Pinocytosis of treponeme, but duct not closed. The structural details of the treponeme are intact outside and inside the cell. $\times 17,000$. Detail $36 \mathrm{~A}$ $\times 40,000$

FIG. 37 Ultrathin section of T. pertenue. The treponeme is in a lysosome, but this is possibly a protective membrane and in the intercellular space. N - nucleus, MN - nuclear membrane, ZG - Golgi zone. $\times 30,000$

FIG. 38 Treponeme inside a cell. Outer wall of treponeme (ME) multi-layered. Endoplasmic reticulum (ER). $\times 27,000$

FIG. 39 Ultrathin section of T. pertenue inside a cell. Section of basal granule and site of insertion of fibrils. $\times 73,000.39 \mathrm{~A}$ shows the same treponeme sectioned closer to the surface FIG. 40 Sections of a treponeme in intercellular spaces. Collagen (KI), mitochondria (MI). $\times 20,000$ FIG. 41 Treponeme in a cell. The structure is well preserved in both longitudinal and crosssection. $\times 53,000$
FIG. 42 Ultrathin section of $T$. pertenue in a rabbit chancre. Endoplastic reticulum (ER) in the cells. The structure of the treponeme is well preserved. $\times 59,000$

FIG. 43 Ultrathin section of $T$. pertenue in a 6-week-old rabbit chancre. Pinocytosis. The treponemes have remained intact. Many treponemes lie in the intercellular space. $\mathrm{N}$ - nucleus, $\mathrm{R}$ - ribosome, $\mathrm{CH}-$ chromatin. $\times 33,000$

FIGS 44 AND 45 Section of treponeme in a rabbit chancre. The treponeme in Fig. 44 lies in a pinosome. MI - mitochondria, PS - pseudopodia, $\mathrm{N}$ - nucleus, $\mathrm{CH}$ - chromatin, $\mathrm{MC}$ - cell membrane. $\times 20,000$

FIG. 46 Ultrathin section of T. pertenue in a wall of blood vessel. Erythrocytes (E) in lumen of vessel. $\times 13,000$

FIG. 47 Treponeme in wall of a blood vessel. $\times 20,000$. Detail $47 A \times 40,000$. $\mathrm{E}-$ erythrocytes, $\mathrm{N}$ - nucleus 

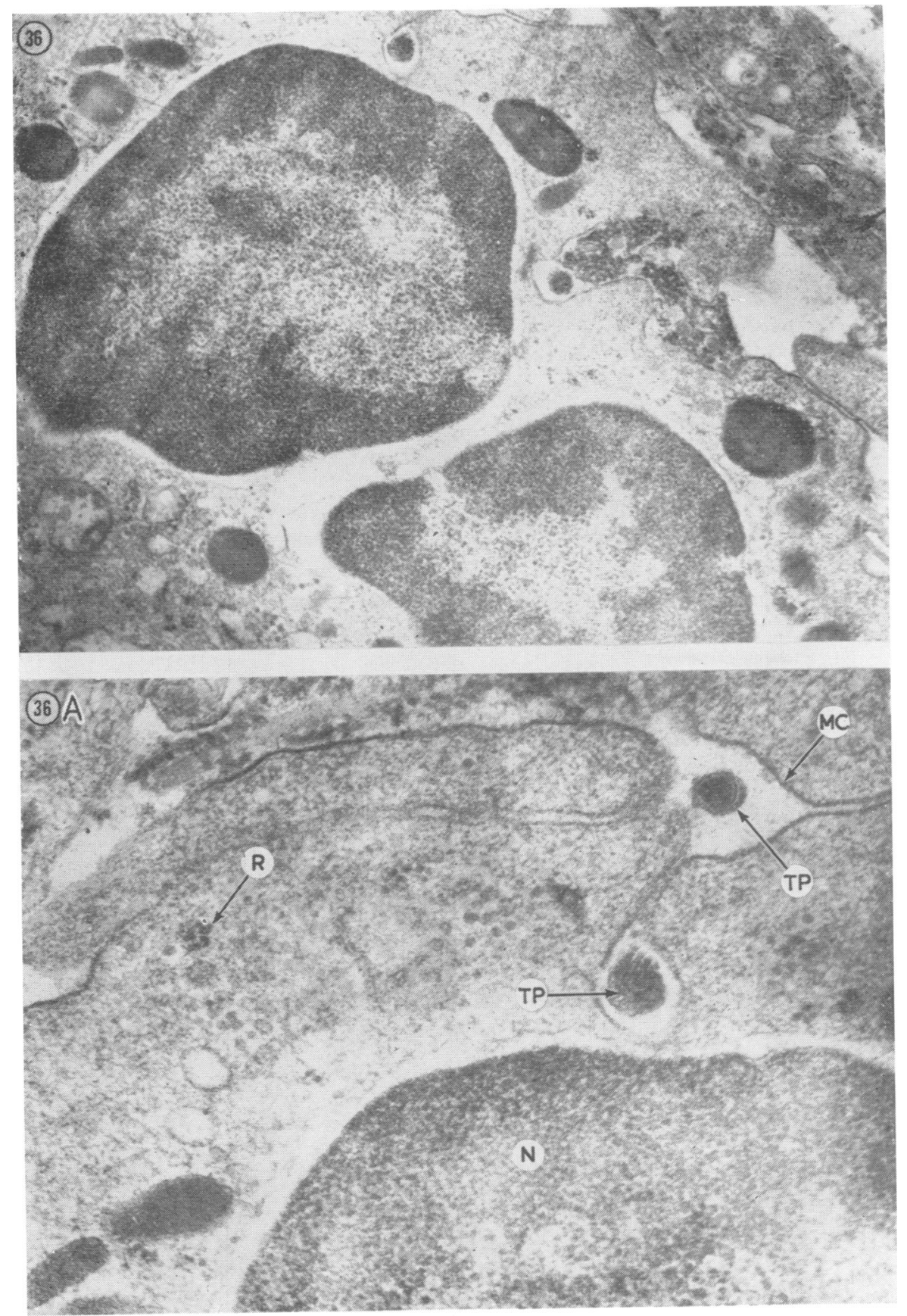

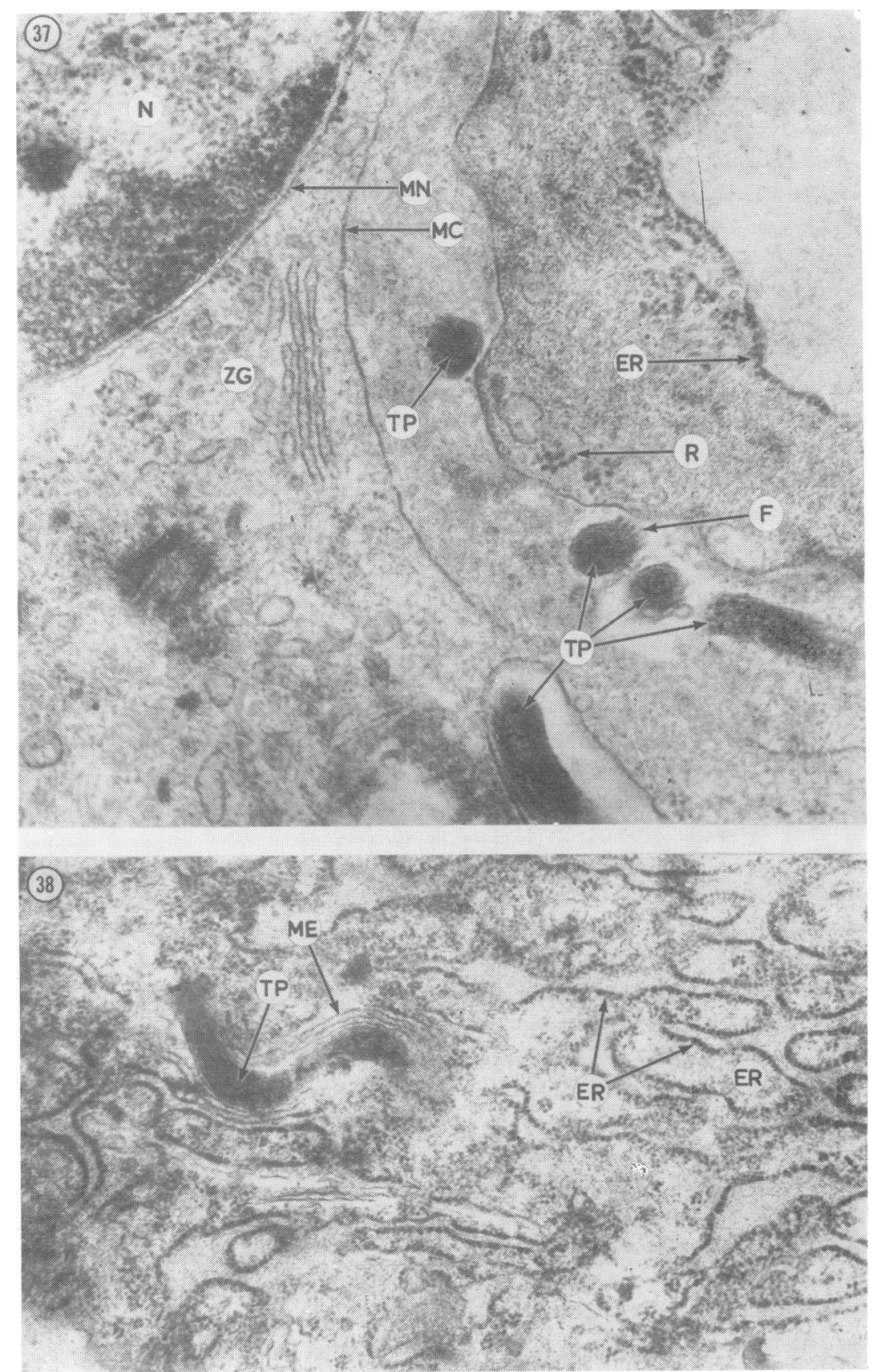

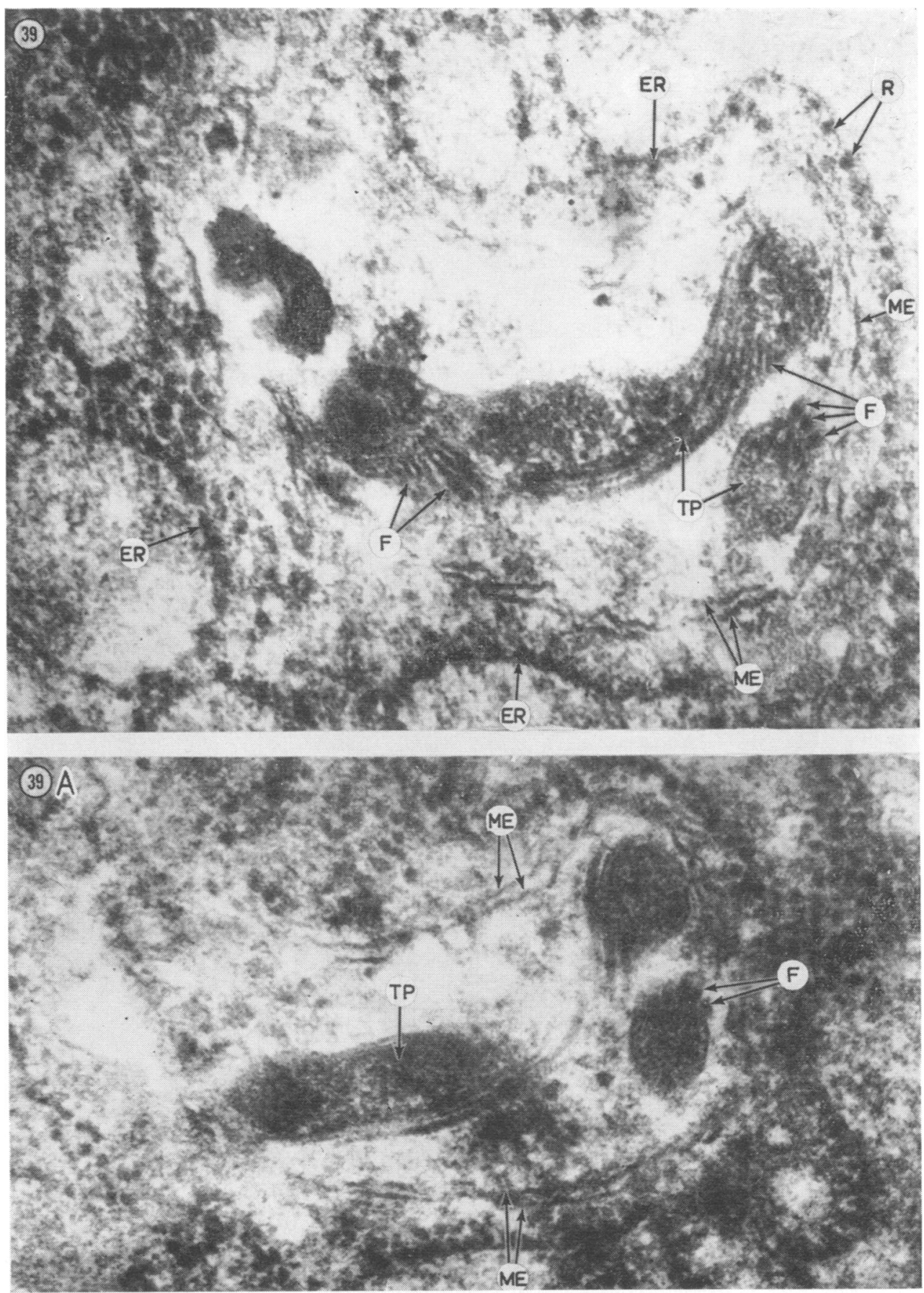

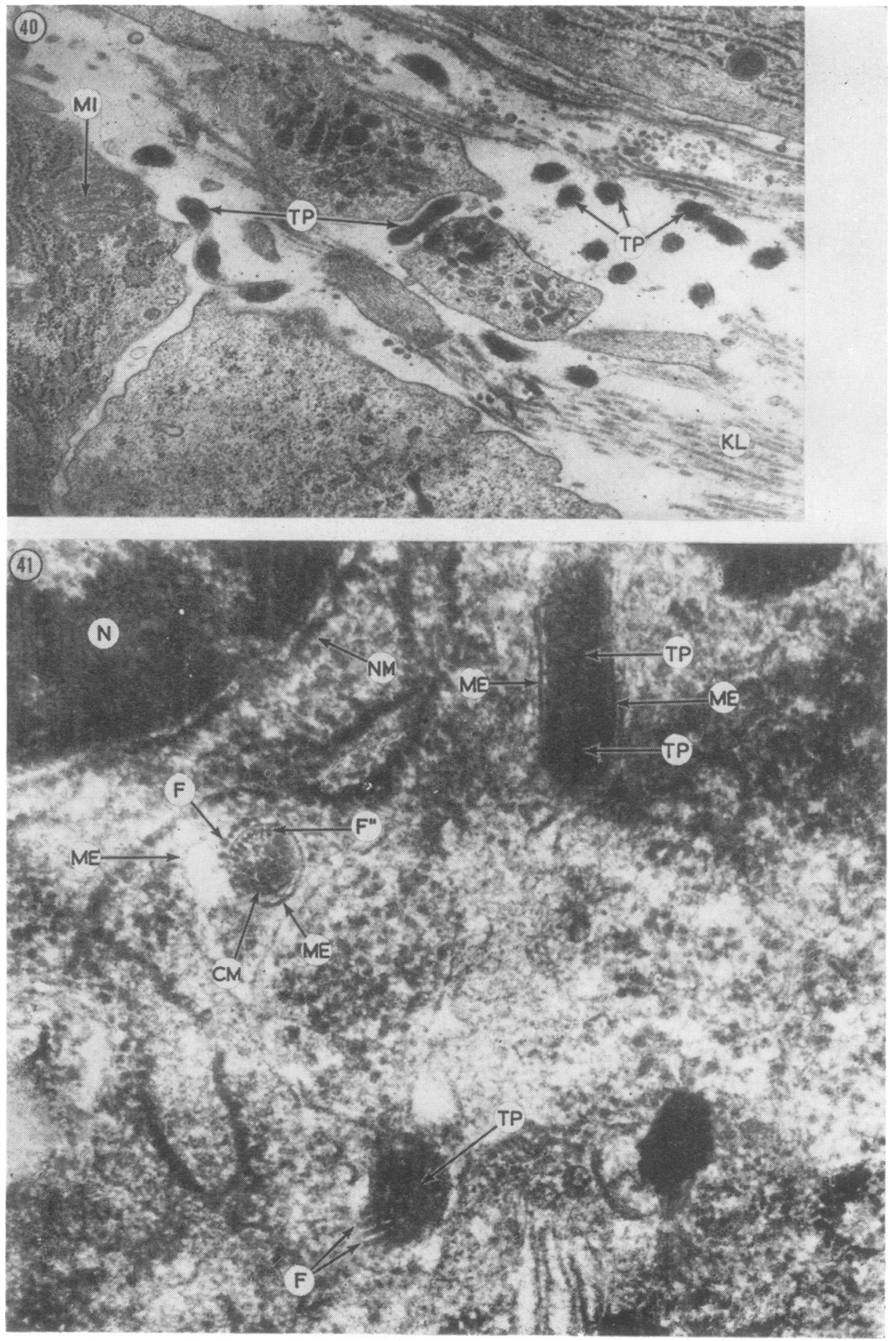

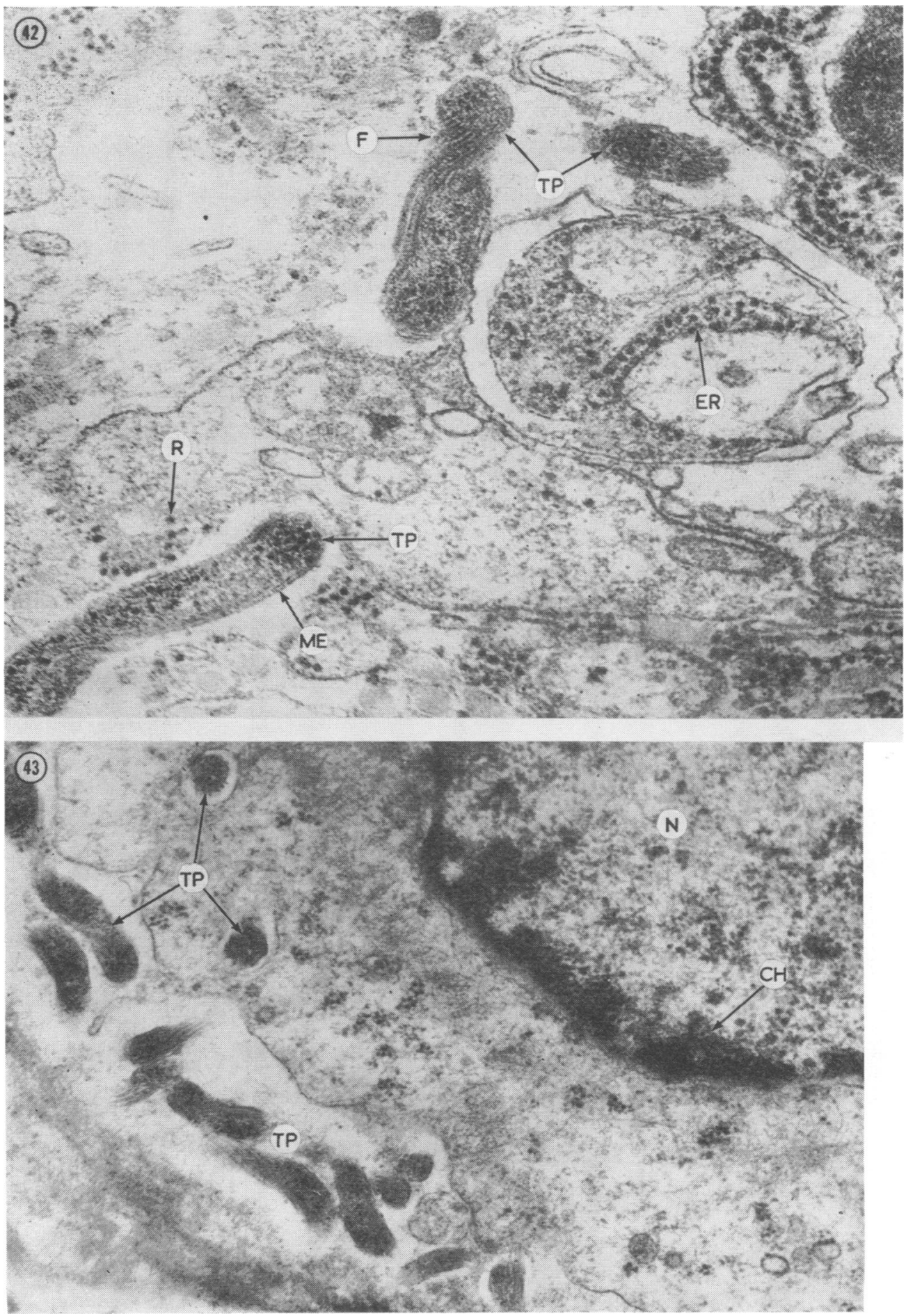

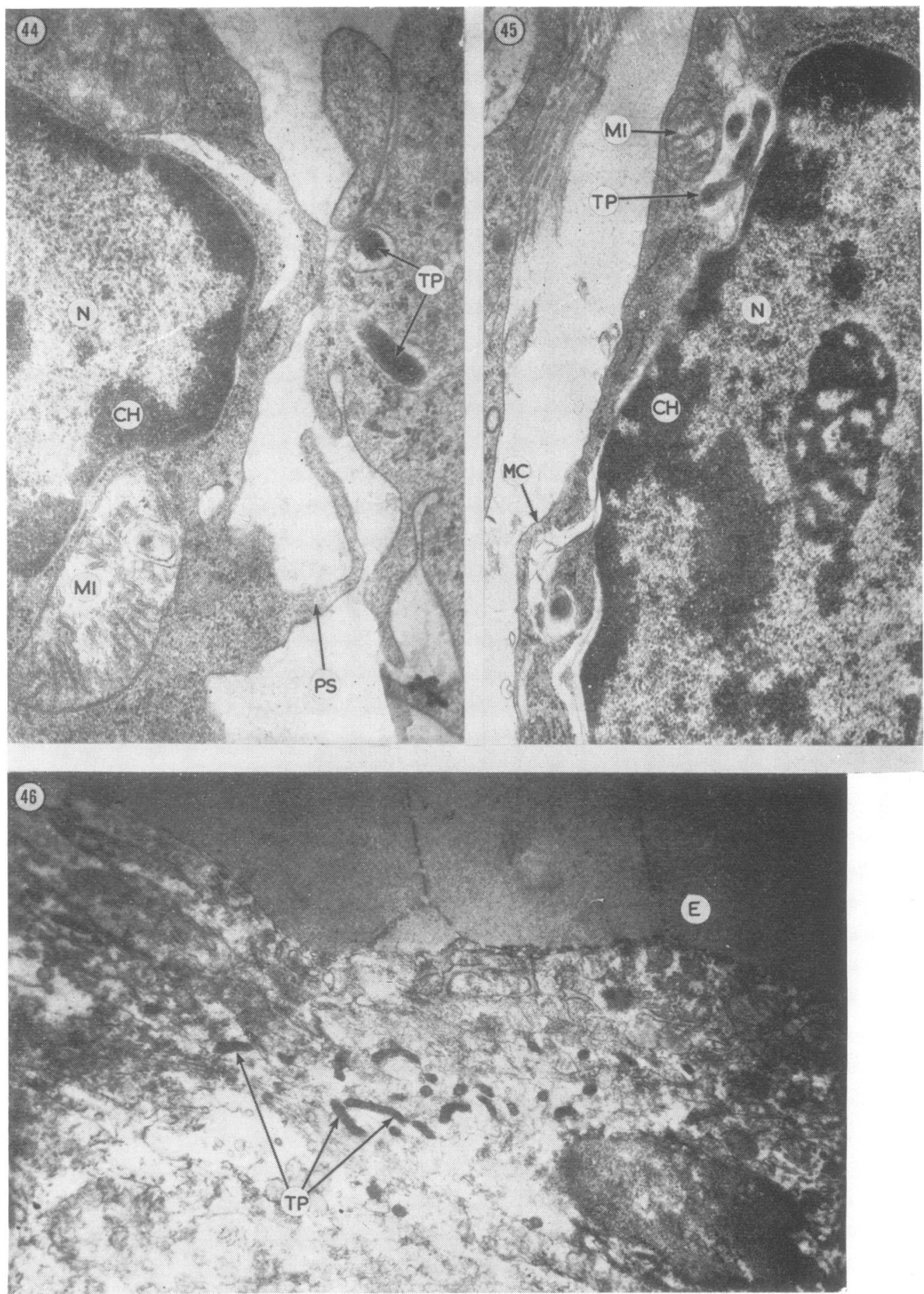


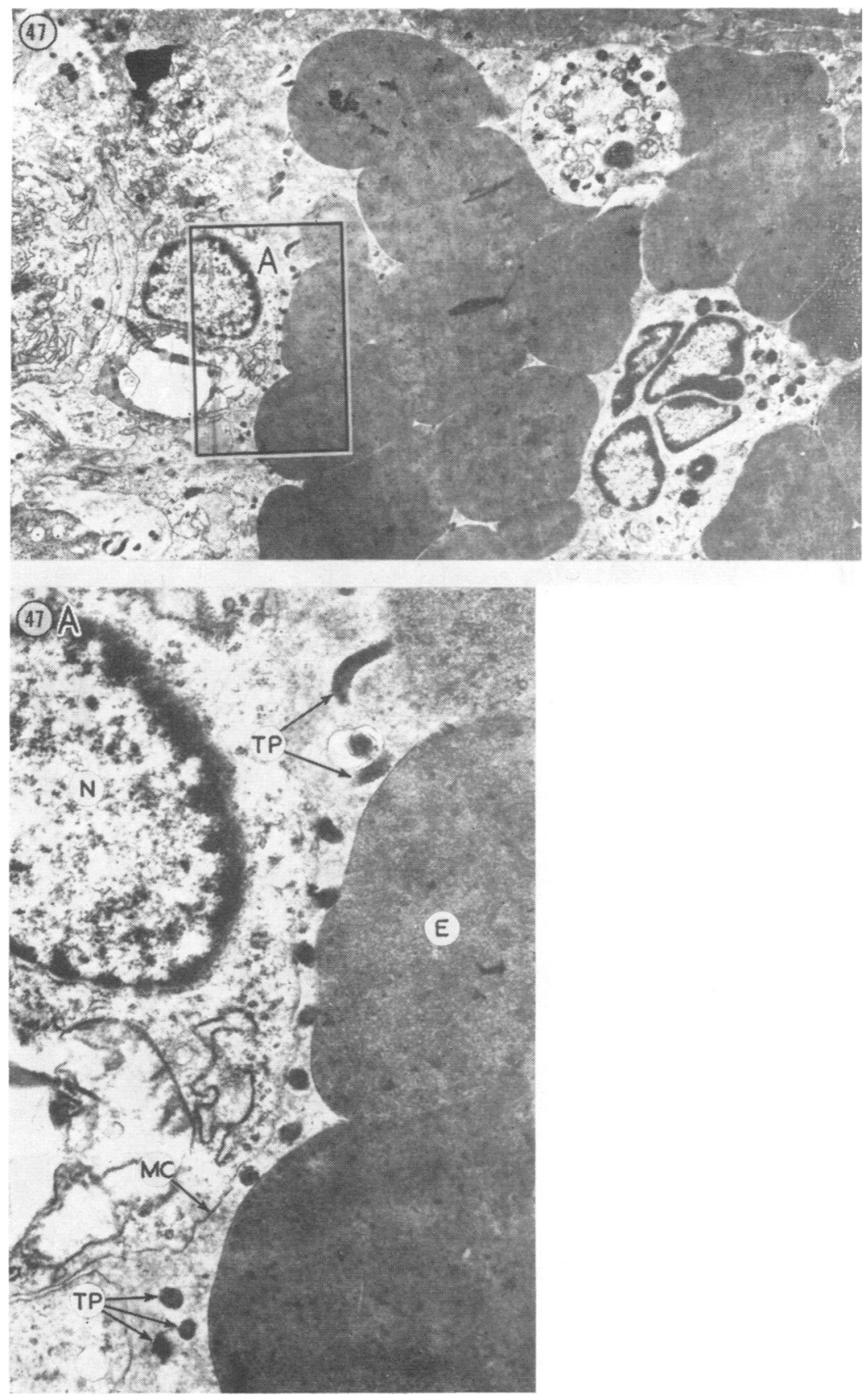

음 
The treponeme may also be found in dilated intercellular spaces around fat droplets (Fig. 48).

Finally, it should be noted that, as in the case of $T$. pallidum, cysts and cyst-like structures may be found in sections of material from nodes in cases of yaws. The cyst-like structures usually have a singlelayered wall and retain the structural features of the treponeme (Fig. 49). The true cysts have a threelayered casing (Fig. 50). The encysted treponeme retains its structure.

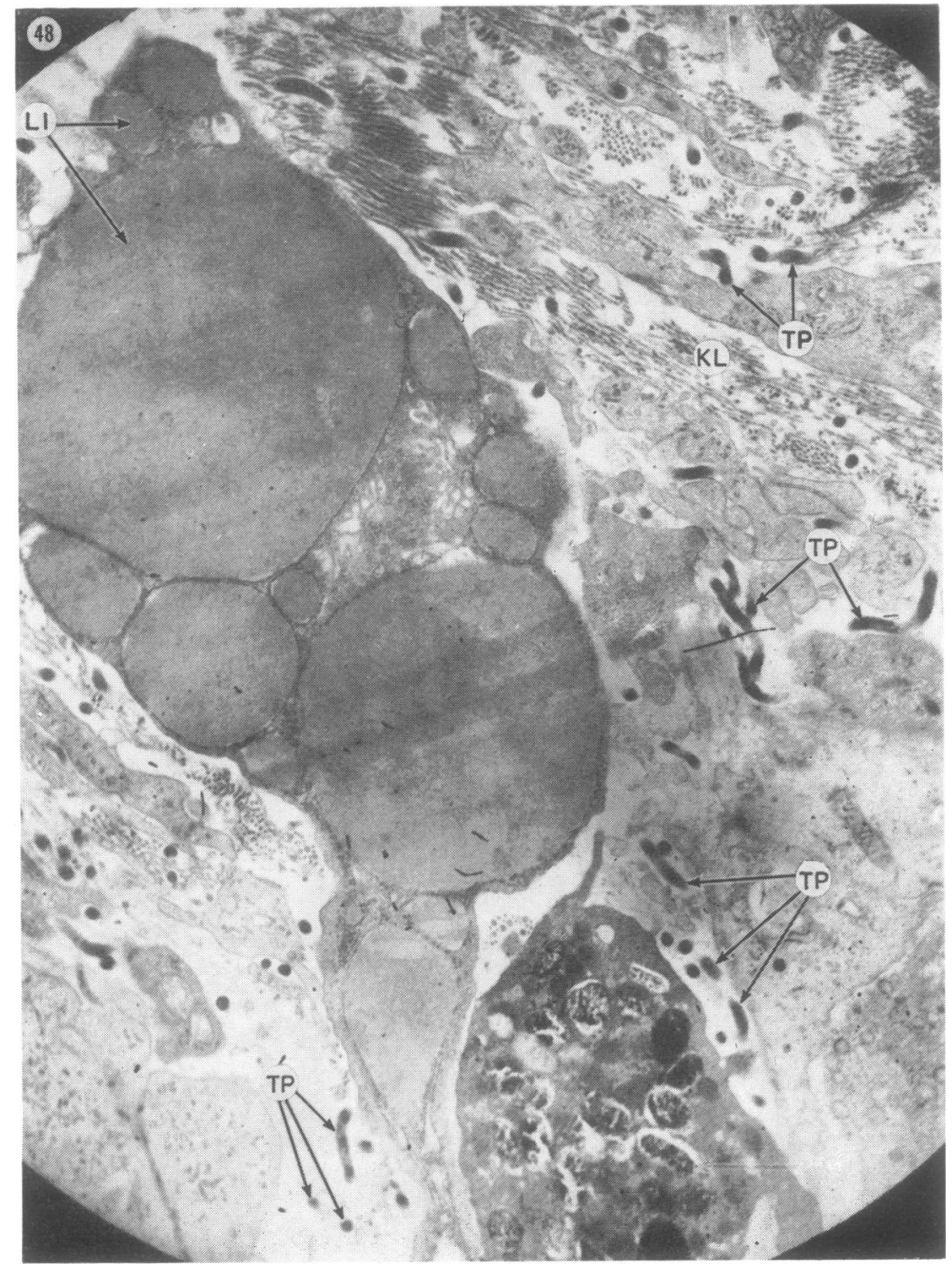

FIG. 48 Ultrathin section of $\mathrm{T}$. pertenue in an intercellular space among young collagen fibres (KL) and fat droplets (LI). $\times 11,000$ 

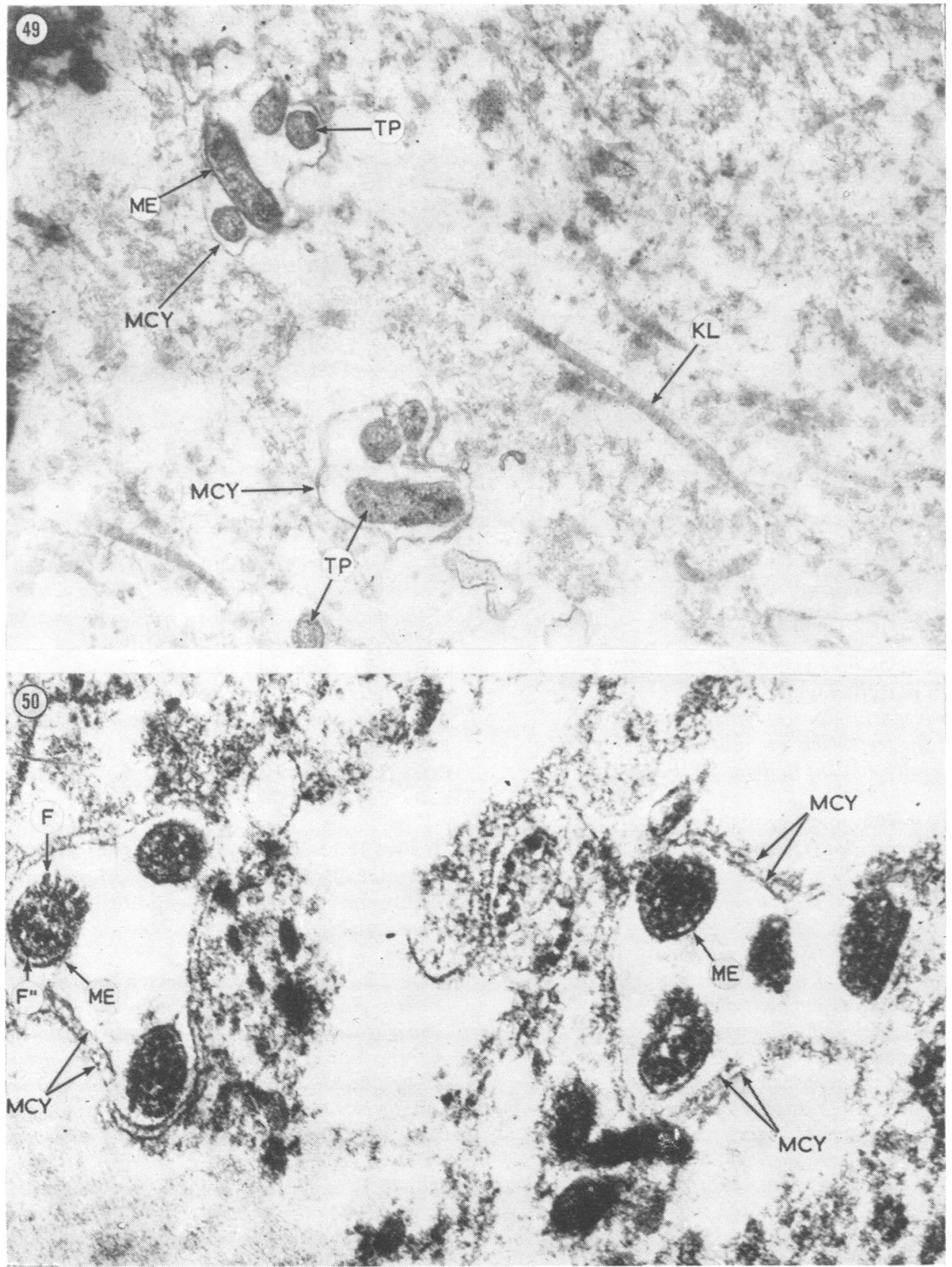

F IG. 49 Ultrathin section of T. pertenue in chancre tissue. $\mathrm{T}$. pertenue in a common envelope (cyst-like structure - cyst?) (MCY) Treponeme in cross-section in tissue. $\times 27,000$
FIG. 50 Ultrathin section of T. pertenue in chancre tissue. Three-layered common envelope (MCY). Structure of treponemes is intact. $\times 33,000$ 
In comparing the structure of $T$. pertenue and $T$. pallidum, it should be noted that we failed to find any reliable structural criteria by which to distinguish them, although structural differences do exist: the longer terminal structures of $T$. pertenue, the slightly different construction of the terminal structures, which still needs further study, the less distinct 'casing' of $T$. pertenue, and the less distinct and less differentiated mesosomes. The difference between cultivated treponemes and $T$. pertenue is more considerable.

\section{References}

Fernando, N. V. P., and Movat, H. Z. (1964) Exp. molec. Path., 3, 1
LuFT, C. H. (1961) f. biophys. biochem. Cytol., 9, 409

Ovčrnnikov, N. M., and DelekTORSKIJ, V. V. (1965)

Vestn. Vener. Derm., 39, No. 1, p. 50

—_ (1966) F. Hyg. Epidem. (Praha), 10, $19 \bar{\jmath}$ (1967) Vestn. Vener. Derm., 41, No. 10, p. 51 (1968) Brit. F. vener. Dis., 44, 1

Palade, G. E. (1952) भ. exp. Med., 95, 285

Pillot, J. (1955) Thèses, Ser. A., No. 4,571. University of Paris, France

Ryter, A., and Pillot, J. (1963) Ann. Inst. Pasteur, 104, 484

SABATINi, D., Bensch, K., and BarRnett, R. J. (1963) $\mathcal{F}$. Cell Biol., 17, 19

TURNER, T. B., and Hollander, D. H. (1950) Bull. fohns Hopk. Hosp., 87, 505

- (1954) Amer. F. Syph., 38, 371

\section{COMPLETE LIST OF LEGENDS AND KEY FOR EASIER REFERENCE}

FIG. 1 T. pertenue under the electron

microscope. Negative-contrast method. $\times 11,000$; details $1 A$ and $1 B \times 53,000$. Mesosomes (M) clearly visible

FIG. 2 Same as Fig. $1 . \times 40,000$

FIG. 3 T. pertenue under the electron

microscope. Negative-contrast method. $\times 30,000$.

The ends of the treponeme are dilated and recurved.

This is especially evident in details $3 A$ and $3 B$. $\times 133,000$

FI G. 4 T. pertenue. Negative-contrast. $\times 133,000$. End of treponeme dilated, shortened, and recurved. Basal granules clearly visible

FI G. 5 T. pertenue. Negative-contrast. End of spongy mass dilated. $\times 53,000$

FIG. 6 T. pertenue. Negative-contrast. Long acuminate end devoid of spongy mass. $\times 53,000$ FIG. 7 T. pertenue among collagen fibres. $\times 30,000$. Structural periodicity of collagen fibres clearly visible. The number of fibrils is not the same in different parts of the treponeme

FIG. 8 T. pertenue (as Fig. 7) See mesosomes FI G. 9 T. pertenue. Negative-contrast. $\times 30,000$. Mesosome (M) in central portion

FIG. 10 T. pertenue. Material from a 6-week-old orchitis. $\times 30,000$. The end of the treponeme is sharply acuminate

FIG. 11 T. pertenue (as Fig. 10) The tip is blunt and basal granules begin from the end

FIGS 12 AND 13 T. pertenue. Negative-contrast. Transverse fission. Fig. $12 \times 133,000$. Fig. 13 $\times 60,000$. The features to be seen are an isthmus $(\mathrm{T})$ at the site of fission and basal granules (B) and fibrils (F) each side of the site of fission
FI G. 14 Longitudinal ultrathin section of

T. pertenue. $\times 113,000$. The three-layered structure of the outer wall (ME) and cytoplasmic membrane (CM) and ribosomes $(\mathrm{R})$ are clearly visible

FIG. 15 Same as Fig. 14. $\times 67,000$

FIGS 16 AND 17 Cross-section of T. pertenue. $\times 100,000$. Outer wall destroyed over fibrils

FIG. $18 \times 53,000$

FIGS 19 AND $20 \times 67,000$

FIG. $21 \quad 100,000$

In Figs 18 to 21 the outer wall (ME) is intact over the outer fibrillar layer ( $F$ ); the cytoplasmic membrane $(\mathrm{CM})$ and the deep fibrillar layer $\left(\mathrm{F}^{\prime \prime}\right)$ are clearly visible

FI G. $22 \times 100,000$. T. pertenue processed by the osmotic-shock method followed by differential centrifugation in a saccharose density gradient. $A$ surface layer of thick fibrils (F) and a deep layer of fine fibrils $\left(\mathrm{F}^{\prime \prime}\right)$ are visible. Insertion on the basal granule is clearly visible in the case of one of the fibrils. The fibrils of the deep layer do not extend to the basal granules

FIGS 23, 24, AND 25 Ultrathin section of $\mathrm{T}$. pertenue in intercellular spaces. The section of material from a lesion on the testicular membranes $\times 30,000$. Triple layering of outer wall (ME) clearly visible

FI G. 26 Same as Fig. 23. $\times 7,000$. Details $26 A$ and $26 B . \times 21,000$. Three-layered outer wall clearly visible. Mitochondria (MI) endoplasmic reticulum (ER), and lysosomes (LS) are seen in the cells in Fig. $26 B$ 
FIG. 27 Ultrathin section of a treponeme (TP) in an intercellular space. $\times 30,000$. Treponemes surrounded by a three-layered 'casing' and others without a 'casing' are seen in the same microscopic field. Outer wall of the treponemes (ME) is intact FIG. 28 Treponeme in intercellular space. Section through a blood vessel. $\times 6,700$. Detail $28 A$ $\times 23,000$. $\mathrm{E}-$ erythrocyte, $\mathrm{MC}-$ cell membrane, $\mathrm{MI}$ - mitochondria, $\mathrm{ER}$ - endoplasmic reticulum, $\mathrm{v}$ - microvilli within the blood vessel, $\mathrm{PC}$ - plasma cell, $\mathrm{LY}$ - lymphocyte, $\mathrm{N}-$ nucleus, $\mathrm{CH}$ - chromatin, MC - cell membrane

FIG. 29 Section of plasma cell from rabbit chancre $\mathrm{N}$ - nucleus, ER - endoplasmic reticulum, $\mathrm{MI}$ - mitochondria, $\mathrm{ZG}$ - Golgi zones, $\mathrm{LY}$ - lysosome, $\mathrm{CH}-$ chromatin. $\times 7,200$. Detail $29 A \times 12,000$ FIG. 30 Ultrathin section of $\mathrm{T}$. pertenue in intercellular spaces around destroyed cells.

Material from 6-week-old chancre on the scrotum. $\times 30,000$. The membranes and the structure of the treponemes appear to be in a 'casing'

FIG. 31 All the membranes of the treponeme are visible; the surface and deep fibrils are clearly outlined in the cross-section; the outer-wall of one treponeme has moved away from the body. $\times 40,000$ FIGS 32 AND 33 Section of T. pertenue in an intercellular space. The structure of the treponeme is intact. $\times 20,000$. Fig. 33 shows a treponeme in the cell cytoplasm. The cells can be seen to contain a nucleus $(\mathrm{N})$ with chromatin $(\mathrm{CH})$ along the periphery and ribosomes $(\mathrm{R})$

FIG. 34 Ultrathin section of $\mathrm{T}$. pertenue in a cell. $\times 20,000$. Detail $34 A \times 100,000$. MN - nuclear membrane

FIG. 35 Ultrathin section of T. pertenue in tissue from node on testicular membrane of a rabbit. The structure of the treponemes is intact both in the intercellular spaces and in a lysosomes (LS) $\times 67,000$

FIG. 36 Ultrathin section of $\mathrm{T}$. pertenue. Pinocytosis of treponeme, but duct not closed. The structural details of the treponeme are intact outside and inside the cell. $\times 17,000$. Detail $36 \mathrm{~A}$ $\times 40,000$

FIG. 37 Ultrathin section of $T$. pertenue. The treponeme is in a lysosome, but this is possibly a protective membrane and in the intercellular space. $\mathrm{N}$ - nucleus, $\mathrm{MN}$ - nuclear membrane, $\mathrm{ZG}$ - Golgi zone. $\times 30,000$

FIG. 38 Treponeme inside a cell. Outer wall of treponeme (ME) multi-layered. Endoplasmic reticulum (ER). $\times 27,000$

FIG. 39 Ultrathin section of T. pertenue inside a cell. Section of basal granule and site of insertion of fibrils. $\times 73,000.39 \mathrm{~A}$ shows the same treponeme sectioned closer to the surface FIG. 40 Sections of a treponeme in intercellular spaces. Collagen $(\mathrm{KL})$, mitochondria $(\mathrm{MI}) . \times 20,000$ FIG. 41 Treponeme in a cell. The structure is well preserved in both longitudinal and crosssection. $\times 53,000$

FIG. 42 Ultrathin section of $\mathrm{T}$. pertenue in a rabbit chancre. Endoplasmic reticulum (ER) in the cells. The structure of the treponeme is well preserved. $\times 59,000$ FIG. 43 Ultrathin section of T. pertenue in a 6-week-old rabbit chancre. Pinocytosis. The treponemes have remained intact. Many treponemes lie in the intercellular space. $\mathrm{N}$ - nucleus, $\mathrm{R}$ - ribosome, $\mathrm{CH}-$ chromatin. $\times 33,000$

FIGS 44 AND 45 Section of treponeme in a rabbit chancre. The treponeme in Fig. 44 lies in a pinosome. MI - mitochondria, PS - pseudopodia, $\mathrm{N}$ - nucleus, $\mathrm{CH}$ - chromatin, $\mathrm{MC}$ - cell membrane. $\times 20,000$

FIG. 46 Ultrathin section of $T$. pertenue in a wall of blood vessel. Erythrocytes (E) in lumen of vessel. $\times 13,000$

FIG. 47 Treponeme in wall of a blood vessel. $\times 20,000$. Detail $47 A \times 40,000$. E - erythrocytes, $\mathrm{N}-$ nucleus

FIG. 48 Ultrathin section of $\mathrm{T}$. pertenue in an intercellular space among young collagen fibres (KL) and fat droplets $(\mathrm{LI}) . \times 11,000$

FIG. 49 Ultrathin section of $\mathrm{T}$. pertenue in chancre tissue. T. pertenue in a common envelope (cyst-like structure - cyst?) (MCY) Treponeme in cross-section in tissue. $\times 27,000$

FIG. 50 Ultrathin section of T.!pertenue in chancre tissue. Three-layered common envelope (MCY). Structure of treponemes is intact. $\times 33,000$

$$
\begin{aligned}
& \text { B - basal granules } \\
& \text { C - treponemal body, cytoplasm } \\
& \text { CH - chromatin } \\
& \text { CM - cytoplasmic membrane } \\
& \text { E - erythrocyte } \\
& \text { ER - endoplasmic reticulum } \\
& \text { F - fibrils } \\
& \text { F" - second layer of fibrils } \\
& \text { KI - collagen fibrils }
\end{aligned}
$$

$$
\begin{aligned}
& \text { N - nucleus } \\
& \text { O - spongy mass } \\
& \text { PC - plasma cell } \\
& \text { PS - pseudopodia } \\
& \text { R - ribosome } \\
& \text { T - site of fission } \\
& \text { TP - Treponema pertenue } \\
& \text { V - microvilli } \\
& \text { ZG - Golgi zone }
\end{aligned}
$$

